\title{
Observation of playa salts as nuclei in orographic wave clouds
}

\author{
Kerri A. Pratt, ${ }^{1,2}$ Cynthia H. Twohy, ${ }^{3}$ Shane M. Murphy, ${ }^{4,5}$ Ryan C. Moffet, ${ }^{6}$ \\ Andrew J. Heymsfield, ${ }^{7}$ Cassandra J. Gaston, ${ }^{8}$ Paul J. DeMott, ${ }^{9}$ Paul R. Field, ${ }^{10}$ \\ Tobias R. Henn, ${ }^{6,11}$ David C. Rogers, ${ }^{12}$ Mary K. Gilles, ${ }^{6}$ John H. Seinfeld, ${ }^{4}$ \\ and Kimberly A. Prather ${ }^{1,8}$
}

Received 10 December 2009; accepted 22 March 2010; published 3 August 2010.

[1] During the Ice in Clouds Experiment-Layer Clouds (ICE-L), dry lakebed, or playa, salts from the Great Basin region of the United States were observed as cloud nuclei in orographic wave clouds over Wyoming. Using a counterflow virtual impactor in series with a single-particle mass spectrometer, sodium-potassium-magnesium-calcium-chloride salts were identified as residues of cloud droplets. Importantly, these salts produced similar mass spectral signatures to playa salts with elevated cloud condensation nuclei $(\mathrm{CCN})$ efficiencies close to sea salt. Using a suite of chemical characterization instrumentation, the playa salts were observed to be internally mixed with oxidized organics, presumably produced by cloud processing, as well as carbonate. These salt particles were enriched as residues of large droplets $(>19 \mu \mathrm{m})$ compared to smaller droplets $(>7 \mu \mathrm{m})$. In addition, a small fraction of silicate-containing playa salts were hypothesized to be important in the observed heterogeneous ice nucleation processes. While the high CCN activity of sea salt has been demonstrated to play an important role in cloud formation in marine environments, this study provides direct evidence of the importance of playa salts in cloud formation in continental North America has not been shown previously. Studies are needed to model and quantify the impact of playas on climate globally, particularly because of the abundance of playas and expected increases in the frequency and intensity of dust storms in the future due to climate and land use changes.

Citation: Pratt, K. A., et al. (2010), Observation of playa salts as nuclei in orographic wave clouds, J. Geophys. Res., 115, D15301, doi:10.1029/2009JD013606.

\section{Introduction}

[2] The effects of aerosol particles on cloud formation and properties represent the largest source of uncertainty in climate prediction [Intergovernmental Panel on Climate Change, 2007]. Certain aerosol particles can serve as cloud condensation nuclei (CCN) or ice nuclei (IN), indirectly affecting climate by changing cloud reflectivity, cloud lifetime, and precipitation patterns [Andreae and Rosenfeld, 2008]. To model current and future climate change, the aerosol population and corresponding cloud nucleating ability must be understood, particularly with regard to spa-

\footnotetext{
${ }^{1}$ Department of Chemistry and Biochemistry, University of California, San Diego, La Jolla, California, USA.

${ }^{2}$ Now at Department of Chemistry, Purdue University, West Lafayette, Indiana, USA.

${ }^{3}$ Department of Oceanic and Atmospheric Sciences, Oregon State University, Corvallis, Oregon, USA.

${ }^{4}$ Division of Chemistry and Chemical Engineering, California Institute of Technology, Pasadena, California, USA.

${ }^{5}$ Now at Chemical Sciences Division, Earth System Research Laboratory, National Oceanic and Atmospheric Administration, Boulder, Colorado, USA.

Copyright 2010 by the American Geophysical Union. 0148-0227/10/2009JD013606
}

tial and temporal variability. The critical supersaturation $\left(\mathrm{S}_{\mathrm{c}}\right)$ at which a particle activates to become a cloud droplet is dependent on particle diameter and chemistry [Andreae and Rosenfeld, 2008]. While chemical composition can be less important than size, it is predicted to have a significant role in the activation of aerosols containing less than approximately $10-15 \%$ soluble material [Junge and McLaren, 1971; Roberts et al., 2002]. Thus, Dusek et al. [2006] suggested that regional and global climate models can assume a "typical" size distribution to estimate $\mathrm{CCN}$ abundance and the effects of aerosols on cloud physics. However,

\footnotetext{
${ }^{6}$ Chemical Sciences Division, Lawrence Berkeley National Laboratory, Berkeley, California, USA

${ }^{7}$ Mesoscale and Microscale Meteorology Division, National Center for Atmospheric Research, Boulder, Colorado, USA.

${ }^{8}$ Scripps Institution of Oceanography, University of California, San Diego, La Jolla, California, USA.

${ }^{9}$ Department of Atmospheric Science, Colorado State University, Fort Collins, Colorado, USA.

${ }^{10}$ Atmospheric Processes and Parameterizations, Met Office, Exeter, $\mathrm{UK}$.

${ }^{11}$ Department of Physics, University of Würzburg, Würzburg, Germany.

${ }^{12}$ Earth Observing Laboratory, National Center for Atmospheric Research, Boulder, Colorado, USA.
} 
Hudson [2007] examined the relationship between particle size and $\mathrm{S}_{\mathrm{c}}$ for a greater range of ambient conditions, showing greater variability than observed by Dusek et al. [2006], particularly for "clean" air masses. Due to variability between different air masses, Hudson [2007] concluded that particle chemistry must be considered to avoid inaccurate estimates of CCN. Recently, Twohy and Anderson [2008] observed salts (chloride and sulfate salts of $\mathrm{Na}, \mathrm{K}$, $\mathrm{Ca}$, and $\mathrm{Mg}$ ) as preferred cloud droplet nuclei for particles $<0.2 \mu \mathrm{m}$ in diameter. However, most cloud studies have focused on marine locations with few studies investigating the chemical composition of clouds in remote continental locations.

[3] Uncoated mineral dust particles are generally assumed to be insoluble, not acting as CCN until becoming coated with sulfate, nitrate, or chloride, for example [Andreae and Rosenfeld, 2008]. However, Twohy et al. [2009] found submicron African dust near the source acted as $\mathrm{CCN}$, and recent work has highlighted the role of dust mineralogy on cloud activation properties [Kelly et al., 2007]. In particular, dust from saline dry lakebeds, or playas, is generally composed of $\sim 10-44 \%$ soluble salts [Abuduwaili et al., 2008; Blank et al., 1999; Reheis, 1997; Singer et al., 2003]. Salt crusts form on playas following rapid evaporation of rainwater or groundwater fluctuations [Reynolds et al., 2007], which concentrates soluble salts at the top surface layer, producing a fluffy, wind-erodible crystalline surface [Blackwelder, 1931; Lowenstein and Hardie, 1985; Russell, 1883]. Common playa evaporite minerals include halite, gypsum, mirabilite, thenardite, epsomite, trona, sylvite, carnallite, calcite/aragonite, dolomite, hanksite, northupite, and aphthitalite [Bryant et al., 1994; Droste, 1961; Güven and Kerr, 1966; Lowenstein and Hardie, 1985]. Chemical analysis of playa dust has shown increased mass fractions of potassium, chloride, sulfate, and sodium with respect to the bulk (deeper) playa soil [Blank et al., 1999].

[4] Playas are present globally [Jones and Deocampo, 2004; Prospero et al., 2002] and contribute to the high global dust burden [Andreae and Rosenfeld, 2008]. Formenti et al. [2003] identified the presence of playa salts within Saharan dust plumes over the Atlantic Ocean. Recent laboratory $\mathrm{CCN}$ measurements demonstrated that a more hygroscopic fraction of playa dust showed $\mathrm{CCN}$ activities similar to sodium chloride; whereas, a less hygroscopic fraction heterogeneously nucleated ice at lower relative humidities than required for homogeneous ice nucleation at temperatures below $-40^{\circ} \mathrm{C}$ [Koehler et al., 2007]. Studies in the western U.S. hypothesized that playa dust may be incorporated into clouds and rained out when air masses encounter mountain ranges [Reheis, 2006; Reheis and Kihl, 1995]. Recent satellite-based studies of Aral Sea dust storms suggest that playa dust particles act as giant $\mathrm{CCN}$ and promote precipitation [Rudich et al., 2002].

[5] Results described herein from the Ice in Clouds Experiment-Layer Clouds (ICE-L) provide the first in situ chemical composition measurements of playa salts within cloud droplets and ice crystals. A highly detailed perspective of the individual cloud residue chemistry is obtained through a unique combination of mass spectrometry and microscopy techniques. CCN measurements are shown for a playa crust sample with similar chemistry to that of the cloud residues sampled during ICE-L. The incorporation of the playa salts within the orographic wave cloud is discussed.

\section{Experimental Methods}

\subsection{Overview and Cloud Sampling}

[6] Measurements in orographic wave clouds were made aboard the National Science Foundation/National Center for Atmospheric Research (NSF/NCAR) C-130 aircraft during ICE-L. In this paper, we primarily focus on measurements made on November 16, 2007 during research flight \#3 (RF03) over Wyoming (41.6-42.8 $\left.\mathrm{N}, 105.8-108.5^{\circ} \mathrm{W}\right)$ at 5.9-7.0 km above mean sea level (MSL). The National Oceanic and Atmospheric Administration (NOAA) Air Resources Laboratory HYSPLIT (Hybrid Single-Particle Lagrangian Integrated Trajectory) model was utilized for air mass trajectory analysis (R. R. Draxler and G. D. Rolph, HYSPLIT (HYbrid Single-Particle Lagrangian Integrated Trajectory) Model, 2003, access via NOAA ARL READY Web site, http://www.arl.noaa.gov/ready/hysplit4. html) (hereinafter Draxler and Rolph, NOAA Web site, 2003). In clear air, an Ultra High Sensitivity Aerosol Spectrometer (UHSAS, Particle Metrics Inc., Boulder, CO) provided size-resolved aerosol number concentrations $(0.1-$ $1.0 \mu \mathrm{m}$ in diameter). Clear air total condensation nuclei (CN) concentrations were measured using a condensation particle counter (CPC, TSI Model 3760), detecting particles $>\sim 13 \mathrm{~nm}$ in diameter.

[7] Cloud particle size distributions, habits and phase were measured with a suite of instruments. Cloud droplet size distributions from 2 to $50 \mu \mathrm{m}$ were measured with a cloud droplet probe (CDP, Droplet Measurement Technologies, Boulder, CO). A two dimensional optical array cloud probe (2D-C, Particle Measuring Systems Inc., Boulder, $\mathrm{CO})$, updated with fast electronics, was used as the primary measurement of number concentrations of cloud ice crystals $>50 \mu \mathrm{m}$ in diameter. The presence of supercooled droplets was detected using a Rosemount icing detector (Model 871, Rosemount Engineering Co., Minneapolis, MN). A cloud particle imager (CPI, Stratton Park Engineering Company Inc., Boulder, $\mathrm{CO}$ ) was used to identify the presence of small droplets, as well as particle habits for particles above $\sim 40-50 \mu \mathrm{m}$.

[8] Cloud residual particles were isolated using a counterflow virtual impactor (CVI) [Noone et al., 1988; Twohy et al., 1997]. The CVI separates individual cloud droplets and ice crystals from interstitial aerosol and gases, collecting and concentrating them within a small flow of high-purity dry nitrogen gas heated to $50^{\circ} \mathrm{C}$. Cloud particles (droplets and ice crystals) with aerodynamic diameters $>7 \mu \mathrm{m}$ were selected using the CVI. Condensed water was evaporated providing individual residual particles for in situ analysis, described below. While cloud particles larger than $\sim 50 \mu \mathrm{m}$ are collected, they may shatter due to inertial forces or upon contact with internal inlet surfaces [Twohy et al., 1997]. The break-up of a large ice crystal may result in more than one residual particle if the initial ice crystal had previously collected liquid droplets or scavenged aerosol particles during its lifetime. Size distributions of the CVI residual particles were measured using an optical particle counter (LAS-Air 1001, Particle Measuring Systems Inc., Boulder, $\mathrm{CO}$ ), which groups particles in eight size ranges between 
Table 1. STEM-EDX Particle Classification Scheme

\begin{tabular}{|c|c|}
\hline Category & STEM-EDX Compositional Signature \\
\hline Crustal dust & $\begin{array}{l}\text { Silicates (rich in } \mathrm{Si} \text {, variable } \mathrm{Na}, \mathrm{Mg}, \mathrm{Al}, \mathrm{K}, \mathrm{Ca} \text {, } \\
\text { and } \mathrm{Fe} \text { ), carbonates (Mg and/or Ca with large } \\
\mathrm{C} \text { peak), phosphates (rare). }\end{array}$ \\
\hline Soot & $\begin{array}{l}\text { Carbon only. Characteristic morphology } \\
\text { (chain aggregates). }\end{array}$ \\
\hline Organic & $\begin{array}{l}\text { Amorphous or irregular and may contain minor } \mathrm{S} \\
\text { and } \mathrm{K} \text {, as well as } \mathrm{C} \text {. }\end{array}$ \\
\hline Sulfates & $\begin{array}{l}\text { Ammonium sulfate/bisulfate and sulfuric acid. } \\
\text { S, O only. }\end{array}$ \\
\hline Industrial Metals & Metals such as $\mathrm{Al}, \mathrm{Fe}, \mathrm{Cr}, \mathrm{Ti}, \mathrm{Mn}, \mathrm{Co}, \mathrm{Zn}, \mathrm{Cu}$. \\
\hline Salts & Combinations of $\mathrm{Na}, \mathrm{K}, \mathrm{Ca}$ and $\mathrm{Mg}$ with $\mathrm{S}$ or $\mathrm{Cl}$. \\
\hline Biomass Salts & Sulfates with potassium, may contain $\mathrm{C}$ as well. \\
\hline Mixed & Combinations of two or more of above categories \\
\hline
\end{tabular}

0.1 and $4.0 \mu \mathrm{m}$ diameter with six second time resolution. Ambient particle impactor samples, described below, were also collected through the CVI inlet by turning off the counterflow, allowing it to function as a simple subisokinetic aerosol inlet.

[9] Aerosol and cloud residue chemical composition were measured using real-time mass spectrometry and microscopy, described below. For CVI data analysis, time periods were divided into three categories: liquid, ice, and mixed phase (both liquid droplets and ice crystals present simultaneously). Generally, cloud particles with aerodynamic diameters $>7 \mu \mathrm{m}$ were selected using the CVI; however, during one cloud period consisting of primarily liquid droplets, $>19 \mu \mathrm{m}$ cloud particles were selected by increasing the counterflow for a higher cut-point. CVI sampling occurred during periods with equivalent potential temperatures $\left(\theta_{\mathrm{e}}\right)$ of 318.3-323.8 K. Thus, for the mass spectrometry analysis, clear air analysis time periods with $\theta_{\mathrm{e}}$ values within this range were chosen for comparison with the in-cloud periods.

\subsection{Aircraft Aerosol Time-of-Flight Mass Spectrometer}

[10] In situ measurements of the size-resolved chemical composition of individual submicron particles were made using the recently developed aircraft aerosol time-of-flight mass spectrometer (A-ATOFMS) [Pratt et al., 2009]. The A-ATOFMS measures, in real-time, the vacuum aerodynamic diameter $\left(d_{v a}\right)$ and dual-polarity mass spectra of individual particles from $\sim 70-1200 \mathrm{~nm}\left(d_{v a}\right)$. Following a ${ }^{210}$ Po neutralizer and pressure-controlled inlet [Bahreini et al., 2008], particles are focused in an aerodynamic lens system. Particles are optically detected by two continuous wave $532 \mathrm{~nm}$ lasers spaced $6.0 \mathrm{~cm}$ apart, providing particle velocity and, thus, $d_{v a}$. Polystyrene latex spheres of known physical diameter from 95 to $1500 \mathrm{~nm}$ were used for the particle size calibration. During ICE-L, particles were desorbed and ionized using $266 \mathrm{~nm}$ radiation from a Q-switched $\mathrm{Nd}$ :YAG laser operating at $\sim 0.4-0.6 \mathrm{~mJ}$. Positive and negative ions resulting from individual particles are detected within the time-of-flight mass spectrometer. For the analysis discussed herein, 283 individual particles were chemically analyzed: 35 particles during clear air sampling, 23 during liquid CVI sampling, 124 during mixed phase CVI sampling, 80 during ice CVI sampling, and 21 during the $19 \mu \mathrm{m}$ cut- point CVI sampling. Standard errors of particle type number percentages were calculated based on Poisson statistics.

[11] Mass spectral peak identifications correspond to the most probable ions for a given $\mathrm{m} / \mathrm{z}$ ratio based on previous lab and field studies. Based on dual-polarity mass spectra, individual particles were divided into 6 categories: salt (Na-K-Mg-Ca-Cl, described in Section 3.1), biomass, organic carbon (OC), soot, sulfate, and other. The mass spectra of the biomass particles, from wildfires and wood combustion, are dominated by potassium $\left(\mathrm{m} / \mathrm{z} 39\left(\mathrm{~K}^{+}\right)\right)$with less intense carbonaceous positive ions [Silva et al., 1999]; most of the biomass particles contained sulfate $(\mathrm{m} / \mathrm{z}-97$ $\left.\left(\mathrm{HSO}_{4}^{-}\right)\right)$, and to a lesser extent, nitrate $\left(\mathrm{m} / z-62\left(\mathrm{NO}_{3}^{-}\right)\right)$. The OC particles were characterized by carbonaceous marker ions at $m / z 12\left(\mathrm{C}^{+}\right), 27\left(\mathrm{C}_{2} \mathrm{H}_{3}^{+} / \mathrm{CHN}^{+}\right), 36\left(\mathrm{C}_{3}^{+}\right)$, and $37\left(\mathrm{C}_{3} \mathrm{H}^{+}\right)$; ammonium $\left(\mathrm{m} / \mathrm{z} 18\left(\mathrm{NH}_{4}^{+}\right)\right)$, amines, and sulfate were typically observed in these particles. Soot particles, dominated by carbon cluster ions $\left(\mathrm{C}_{\mathrm{n}}^{+-}\right)$, were often mixed with potassium and sulfate; a fraction of these particles contained organic carbon markers as well. Sulfate particles were characterized by having only negative ion mass spectra with intense peaks at $m / z-97\left(\mathrm{HSO}_{4}^{-}\right)$and $-195\left(\mathrm{H}_{2} \mathrm{SO}_{4} \mathrm{HSO}_{4}^{-}\right)$. The "other" particle category contains less abundant particles, such as biological particles and particles producing only negative ion mass spectra containing both nitrate and sulfate.

\subsection{Scanning Transmission Electron Microscopy: Energy Dispersive X-Ray Analysis}

[12] Downstream of the CVI inlet, a two-stage round-jet impactor [Rader and Marple, 1985] allowed separation of particles by size. At typical sampling pressures of $500 \mathrm{mb}$, the small particle impactor plate collected 0.11 to $0.59 \mu \mathrm{m}$ diameter unit-density particles, or 0.08 to $0.42 \mu \mathrm{m}$ diameter $1.7 \mathrm{~g} \mathrm{~cm}^{-3}$ density particles. The large particle plate collected larger particles up to several microns in size. Particles were impacted onto transmission electron microscope grids (nickel base coated with formvar and carbon) and were analyzed individually via scanning transmission electron microscopy (STEM) with energy dispersive X-ray analysis (EDX). Note that some organics and nitrates volatilize under the vacuum environment of the microscope. Approximately 50-100 particles were randomly selected and analyzed per stage per sample. The clear air sample was taken at $\theta_{\mathrm{e}}$ values of 315.9-317.2 K, which is lower than the $\theta_{\mathrm{e}}$ values during cloud sampling; thus, the air probably did not flow into the cloud from this level. The mixed-phase CVI sample was collected at $\theta_{\mathrm{e}}$ of $321.7-322.3 \mathrm{~K}$.

[13] For STEM-EDX analysis, particles were classified into eight primary types as given in Table 1. "Mixed" types were particles described by multiple categories; for example, crustal dust with sulfate or salts as these may be important for their role as both IN and CCN. Particles were classified as "unknown" if they did not fit into any of the specific categories or did not produce detectable X-ray signatures above background (for example, volatile organics or nitrates). This is the same classification scheme as used by Twohy and Anderson [2008], with the addition of the biomass category which would have been included in the "salts" category in previous work. Standard errors of particle type number percentages were calculated based on Poisson statistics. 


\subsection{Compact Time-of-Flight Aerosol Mass Spectrometer}

[14] The Aerodyne compact time-of-flight aerosol mass spectrometer (C-ToF-AMS) [Drewnick et al., 2005] measured the mass concentrations of non-refractory species (organics, sulfate, nitrate, ammonium, and a fraction of chloride) in real-time. Following a pressure-controlled inlet [Bahreini et al., 2008], particles of $d_{v a} \sim 50-800 \mathrm{~nm}$ are focused by an aerodynamic lens system, sent through a $3.5 \%$ chopper, and then impacted onto a tungsten vaporizer operated at $550-560^{\circ} \mathrm{C}$. The chopper can be operated in three modes to gather either background mass spectra, ensemble average mass spectra over all particle sizes, or size-resolved mass spectra. Measurements of chloride and other semi-refractory species are reported herein, but concentrations of these species are significantly underestimated by the C-ToF-AMS because they are not efficiently volatilized at the vaporizer temperature $\left(550-560^{\circ} \mathrm{C}\right)$ used. Once vaporized, molecules undergo electron impact ionization and are extracted at a rate of $\sim 53 \mathrm{kHz}$ into a time-of-flight mass analyzer.

[15] Detection limits for out of cloud aerosol were calculated as the standard deviation of the noise when measuring filtered air: organics $\left(0.06 \mu \mathrm{g} / \mathrm{m}^{3}\right)$, sulfate $\left(0.02 \mu \mathrm{g} / \mathrm{m}^{3}\right)$, nitrate $\left(0.01 \mu \mathrm{g} / \mathrm{m}^{3}\right)$, ammonium $\left(0.07 \mu \mathrm{g} / \mathrm{m}^{3}\right)$, and chloride $\left(0.01 \mu \mathrm{g} / \mathrm{m}^{3}\right)$. Detection limits for measurements made in cloud were calculated as the standard deviation of measurements made on the CVI inlet during cloud-free periods: organics $\left(0.003 \mu \mathrm{g} / \mathrm{m}^{3}\right)$, sulfate $\left(0.0006 \mu \mathrm{g} / \mathrm{m}^{3}\right)$, nitrate $\left(0.0007 \mu \mathrm{g} / \mathrm{m}^{3}\right)$, ammonium $\left(0.0007 \mu \mathrm{g} / \mathrm{m}^{3}\right)$, and chloride $\left(0.0005 \mu \mathrm{g} / \mathrm{m}^{3}\right)$. In practice, detection is often limited by counting statistics at low aerosol loadings. Lower detection limits during CVI sampling were due to the enrichment of particles by the CVI and entrainment in $\mathrm{N}_{2}$ (rather than air) which reduces the noise at certain organic $m / z$ 's. Corrections for CVI enhancements (typically a factor of $20-30$ ) were completed for reported detection limits and mass concentrations. One important issue concerning C-ToF-AMS data is the collection efficiency (CE) of particles within the instrument [Huffman et al., 2005]; in this study, C-ToFAMS mass loadings were not corrected for $\mathrm{CE}$ due to the lack of another mass measurement on the plane and because of possible changes in particle phase [Matthew et al., 2008] between clear air and CVI dry residue sampling. By not adjusting the mass loadings for $\mathrm{CE}$, we are effectively assuming a collection efficiency of 1 , although we note that the CE likely varied during the flight. Standard deviations are noted as uncertainties for average species mass fractions. Oxygen/carbon $(\mathrm{O} / \mathrm{C})$ ratios were calculated from unit resolution mass spectra following the estimation method developed by Aiken et al. [2008]:

$$
\mathrm{O} / \mathrm{C}=(0.0382 \pm 0.0005)(\mathrm{x})+(0.0794 \pm 0.0070)
$$

where $\mathrm{x}$ is the percentage of organic aerosol mass from $m / z \quad 44\left(\mathrm{CO}_{2}^{+}\right)$.

\subsection{Scanning Transmission X-Ray Microscopy-Near Edge X-Ray Absorption Fine Structure Spectroscopy}

[16] Three large stage impactor samples, collected as described in Section 2.3, were analyzed with scanning transmission X-ray microscopy (STXM) with near edge
X-ray absorption fine structure spectroscopy (NEXAFS) at Lawrence Berkeley National Laboratory's Advanced Light Source (ALS) [Kilcoyne et al., 2003]. The clear air sample was taken at $\theta_{\mathrm{e}}$ values of $320.2-322.1 \mathrm{~K}$, which is within the $\theta_{\mathrm{e}}$ values of cloud sampling. The ice phase CVI sample was collected at $\theta_{\mathrm{e}}$ of $319.0-323.1 \mathrm{~K}$; similarly, the $19 \mu \mathrm{m}$ cut-point CVI sample was collected in primarily liquid phase at $\theta_{\mathrm{e}}$ of 319.3-322.8 K. For each sample region of interest, $\sim 100$ images were acquired over the carbon $\mathrm{K}$ edge from 278 to $320 \mathrm{eV}$. Peaks arising from the potassium $\mathrm{L}_{2}$ and $\mathrm{L}_{3}$ edges occur at $\sim 299$ and $297 \mathrm{eV}$ respectively. For some of the carbonate samples, the presence of calcium was confirmed at the $\mathrm{L}_{2}$ and $\mathrm{L}_{3}$ edges occurring at 353 and $349 \mathrm{eV}$ respectively [Henke et al., 1993].

[17] Maps of elemental carbon (EC), organic carbon, potassium, and regions rich in non-carbon elements (inorganic, In) were used to classify the different particle types seen in the different samples (R. C. Moffet et al., Automated assay of internally mixed individual particles using X-ray spectromicroscopy maps, submitted to Analytical Chemistry, 2010). EC regions were identified as those regions containing greater than $35 \%$ carbon-carbon $\mathrm{sp}^{2}$ hybridized double bonds [Hopkins et al., 2007]. The pre-edge region occurring around $278 \mathrm{eV}$ is proportional to the number of non-carbon atoms, and the difference between the postedge and pre-edge regions is proportional to the number of carbon atoms. In regions were identified by the ratio of the pre-edge height to post edge height $\left(\mathrm{h}_{\text {pre }} / \mathrm{h}_{\text {post }}\right)$; if $\mathrm{h}_{\text {pre }} / \mathrm{h}_{\text {post }}$ was greater than 0.4 , the area is defined as being dominated by inorganic material on a thickness basis. Finally, if an area contained absorbance due to $\mathrm{COOH}$ groups at $288 \mathrm{eV}$ (near the carbon edge), the region was identified as containing OC. Particle class labels (OC, OCEC, OCECIn, and OCIn) were used to identify particles that contain one or more of these three components (In, OC and/or EC).

\subsection{Continuous Flow Diffusion Chamber}

[18] To measure the number concentrations of ice-nucleating aerosol particles in real-time, a continuous flow diffusion chamber (CFDC) [Eidhammer et al., 2010; Rogers et al., 2001] re-processed cloud residues near the cloud observation temperature and at a relative humidity (with respect to water) exceeding $100 \%$ to simulate ice formation conditions at expected wave cloud parcel entry conditions. This means of operating the CFDC emphasized condensation/immersion freezing nucleation as is expected for the cloud entry regions of orographic wave clouds on the basis of previous studies [Cooper and Vali, 1981]. Use of an impactor limited sampling to primarily submicron particles $(<\sim 1.5 \mu \mathrm{m}$ in diameter) prior to CFDC processing in order to distinguish ice crystals nucleated in the CFDC from nonactivated aerosol particles using optical methods.

\subsection{Laboratory Measurements}

[19] For comparison to ICE-L results, dry lakebed crust particles collected from the surface of Owens (dry) Lake, CA were aerosolized by dry generation using $\mathrm{N}_{2}$, as detailed previously by Sullivan et al. [2009]. The dust potential and chemistry of Owens Lake has been studied in detail [e.g., Cahill et al., 1996; Gill et al., 2002], making it a good comparison source; however, this does not suggest it as the exact source of the ICE-L particles. The A-ATOFMS, 


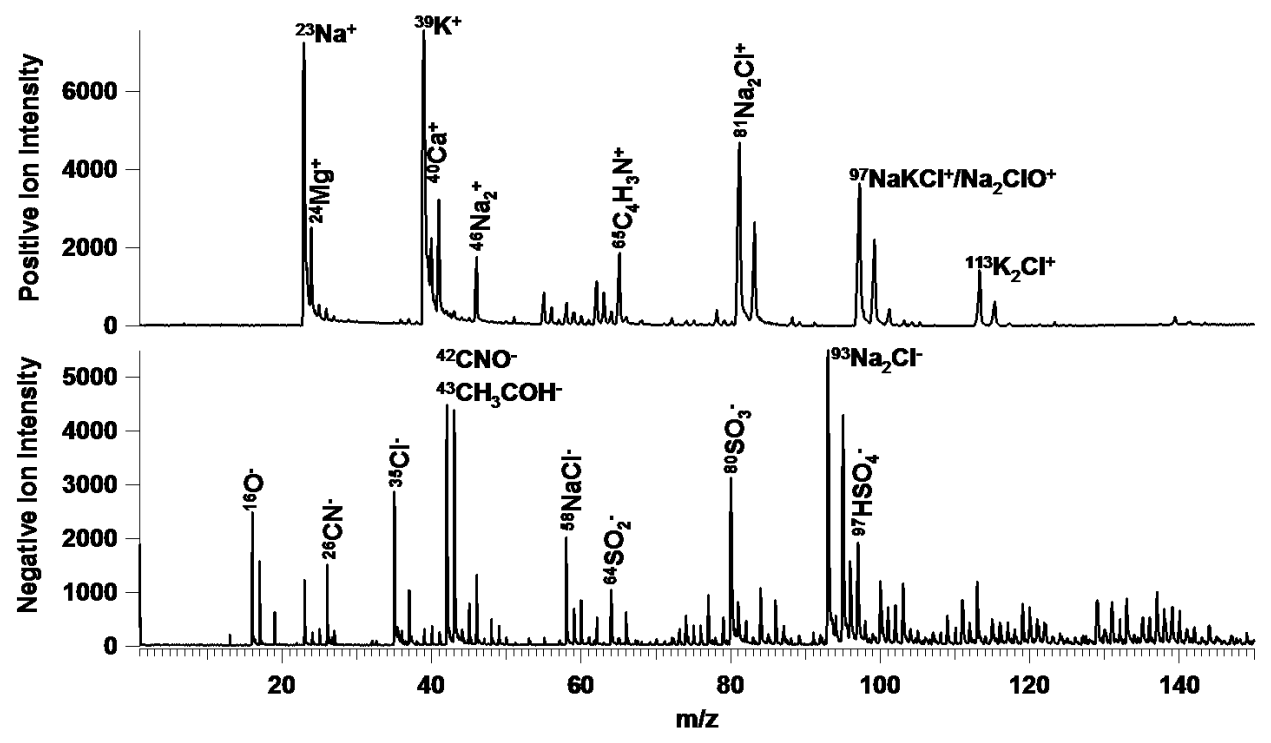

Figure 1. Representative A-ATOFMS positive and negative ion mass spectra of a single cloud droplet residue salt.

described above, was used to measure particle chemistry in tandem with measurements of $\mathrm{CCN}$ activity. For CCN analysis, aerosolized particles were passed through a ${ }^{210} \mathrm{Po}$ neutralizer and then size-selected $(80,90$, and $100 \mathrm{~nm})$ using a differential mobility analyzer (DMA, Model 3081, TSI inc.) to obtain a monodisperse aerosol distribution. Total particle concentrations were measured by a condensation particle counter (CPC, Model 3010, TSI Inc.) and compared to the number concentrations of particles activated within a miniature cloud condensation nuclei counter (CCNc) at supersaturations of $\sim 0.1-1.1 \%$ [Roberts and Nenes, 2005]. The supersaturation of the $\mathrm{CCNc}$ is a function of the column temperature gradient (dT), which was calibrated using $\left(\mathrm{NH}_{4}\right)_{2} \mathrm{SO}_{4}$ (Aldrich, $99.999 \%$ purity). Activation curves of $\mathrm{CCN} / \mathrm{CN}$ ratios, providing the fraction of activated particles, were generated by scanning through supersaturations (column dT) at a fixed dry diameter; the $\mathrm{S}_{\mathrm{c}}$ is defined as $\mathrm{CCN} / \mathrm{CN}=0.5$. The contribution of multiply charged particles was corrected using the method of Rose et al. [2008]. Herein, CCN activity is presented as the single hygroscopicity parameter kappa $(\kappa)$ [Petters and Kreidenweis, 2007], which was determined by plotting $S_{c}$ for each dry diameter $\left(D_{d}\right)$ on a log-log plot with the different $S_{c}-D_{d}$ pairs for each sample falling on $\kappa$ isolines. Uncertainty in $\kappa$ is from errors associated with the $\mathrm{CCNc}$ supersaturation calibration and from selecting a monodisperse aerosol using a DMA.

\section{Results and Discussion}

\subsection{Single-Particle Mixing State and Origin of Playa Salts}

[20] While flying through mixed-phase orographic wave clouds over Wyoming during ICE-L, the A-ATOFMS identified playa salts among the residues of cloud droplets and ice crystals. Figure 1 shows example A-ATOFMS positive and negative ion mass spectra of an individual salt residue from a RF03 evaporated cloud droplet. These salt particles were characterized by intense sodium $\left(m / z 23, \mathrm{Na}^{+}\right)$, magnesium $\left(\mathrm{m} / \mathrm{z} 24, \mathrm{Mg}^{+}\right)$, potassium $\left(\mathrm{m} / \mathrm{z} 39, \mathrm{~K}^{+}\right)$, and calcium $(\mathrm{m} / \mathrm{z}$ $\left.40, \mathrm{Ca}^{+}\right)$ion peaks with less intense positive ions at $\mathrm{m} / \mathrm{z}$ 55 $\left(\mathrm{KO}^{+}\right), 56\left(\mathrm{KOH}^{+} / \mathrm{CaO}^{+}\right), 81\left(\mathrm{Na}_{2} \mathrm{Cl}^{+}\right)$, and $97\left(\mathrm{Na}_{2} \mathrm{ClO}^{+}\right)$. The negative ion mass spectra featured distinguishing peaks at $m / z-16\left(\mathrm{O}^{-}\right),-17\left(\mathrm{OH}^{-}\right),-26\left(\mathrm{CN}^{-}\right),-35\left(\mathrm{Cl}^{-}\right),-42\left(\mathrm{CNO}^{-}\right)$, $-58\left(\mathrm{NaCl}^{-}\right)$, and $-93\left(\mathrm{NaCl}_{2}^{-}\right)$. The high relative intensities of the magnesium, calcium, and negative ion organic nitrogen markers, in particular, distinguish these playa salts from sea salt [Gard et al., 1998]. A fraction of the negative ion mass spectra also contain carbon cluster ions $\left(C_{n}\right)$, silicates, phosphate, nitrate, and/or sulfate. The mass spectral signatures of these salts are expected for the typical evaporite minerals associated with playas, including halite $(\mathrm{NaCl})$, gypsum $\left(\mathrm{CaSO}_{4} \cdot 2 \mathrm{H}_{2} \mathrm{O}\right)$, mirabilite $\left(\mathrm{Na}_{2} \mathrm{SO}_{4} \cdot 10 \mathrm{H}_{2} \mathrm{O}\right)$, thenardite $\left(\mathrm{Na}_{2} \mathrm{SO}_{4}\right)$, epsomite $\left(\mathrm{MgSO}_{4} \cdot 7 \mathrm{H}_{2} \mathrm{O}\right)$, trona $\left(\mathrm{NaHCO}_{3} \cdot \mathrm{Na}_{2} \mathrm{CO}_{3} \cdot 2 \mathrm{H}_{2} \mathrm{O}\right)$, sylvite $(\mathrm{KCl})$, carnallite $\left(\mathrm{KCl} \cdot \mathrm{MgCl}_{2} \cdot 6 \mathrm{H} 2 \mathrm{O}\right)$, calcite/aragonite $\left(\mathrm{CaCO}_{3}\right)$, dolomite $\left(\mathrm{CaMg}\left(\mathrm{CO}_{3}\right)_{2}\right)$, hanksite $\left(\mathrm{Na}_{22} \mathrm{~K}\left(\mathrm{SO}_{4}\right)_{9}\left(\mathrm{CO}_{3}\right)_{2} \mathrm{Cl}\right.$, northupite $\left(\mathrm{Na}_{3} \mathrm{Mg}\left(\mathrm{CO}_{3}\right)_{2} \mathrm{Cl}\right)$, and aphthitalite $\left(\mathrm{K}_{2} \mathrm{SO}_{4}\right)$ [Bryant et al., 1994; Droste, 1961; Güven and Kerr, 1966; Lowenstein and Hardie, 1985].

[21] To further confirm the A-ATOFMS salt signature as from playa dust, dry lakebed crust particles from Owens Lake, CA were compared using the A-ATOFMS analysis method of Toner et al. [2008]. The average mass spectral signature of the Owens Lake crust was compared to the average mass spectrum of the cloud residue salts using calculated dot products for the ion peaks in the spectra. Lower dot products indicate less similarity between the two sets of particles; whereas high dot products indicate greater similarity. In this case, the mass spectral comparison showed a strong similarity (dot product $=0.7)$ between the Owens Lake crust and cloud residue salt particles, supporting the ICE-L signature as playa dust, as opposed to sea salt (dot product $=0.58)$; it is important to note that a higher 


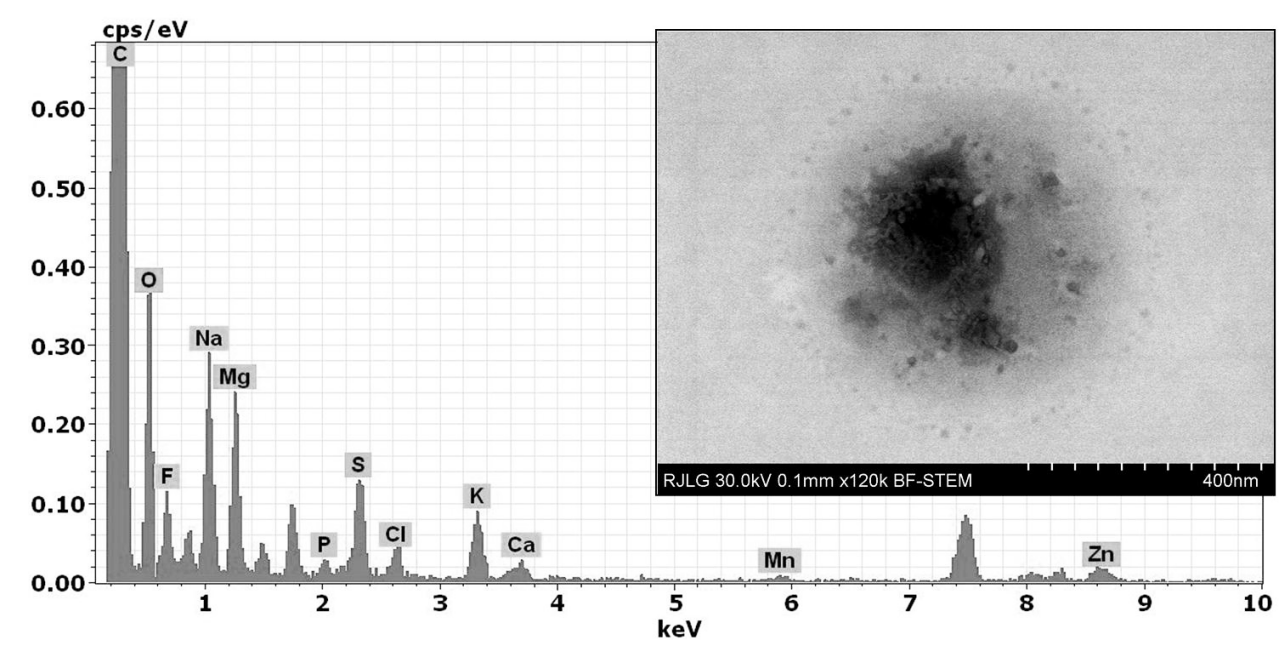

Figure 2. STEM image of cloud residue salt with corresponding EDX spectrum.

dot product would likely be obtained if the exact playa source of the cloud residues could have been measured, particularly at the time of the dust lofting.

[22] STEM-EDX analysis of cloud residues also showed the presence of salts, defined as containing $\mathrm{Na}, \mathrm{K}, \mathrm{Ca}$, and $\mathrm{Mg}$ with $\mathrm{S}$ or $\mathrm{Cl}$ (Table 1). An example STEM image and corresponding EDX spectrum are shown in Figure 2 for a single RF03 cloud residue salt, likely from a liquid droplet. In addition to the salt-defining elements, this particle contains $\mathrm{C}, \mathrm{O}, \mathrm{F}, \mathrm{Zn}$, and $\mathrm{P}$ above background levels. This signature is in excellent agreement with that determined by A-ATOFMS, as discussed above, as well as previous proton-induced X-ray emission (PIXE) analysis of playa sediments, where samples contained $\mathrm{Na}, \mathrm{Ca}, \mathrm{Si}$, and trace metals [Gill et al., 2002]. By comparison, for Owens Lake (CA) playa sediments, silicon and aluminum contents ranged from $\sim 16-22 \%$ and $\sim 3-5 \%$ by mass, respectively; $\mathrm{Zn}$ content was found to be $\sim 46-100 \mathrm{ppm}$ [Gill et al., 2002]. It should also be noted that a "halo" surrounds the solid residue salt shown in Figure 2. During previous aircraft-based aerosol sampling over Montana, $\mathrm{NaCl}$ particles from the Great Salt Lake area were detected simultaneously with soil particles [Hobbs et al., 1985]. Using scanning electron microscopy (SEM)EDX, "haloes" containing Si and $\mathrm{Cl}$ with trace $\mathrm{S}$ were found surrounding soil particles containing $\mathrm{Si}$ and $\mathrm{Al}$ with trace $\mathrm{Fe}$ and $\mathrm{K}$ [Hobbs et al., 1985].

[23] To further characterize the cloud residue salts with particular focus on the organic component, STXM/NEXAFS was utilized to examine the $\mathrm{EC}, \mathrm{OC}, \mathrm{K}$, and regions rich in In elements within individual particles. Figure 3 shows chemical component maps for a single mixed organic/ inorganic (OCIn) RF03 cloud residue collected during the $19 \mu \mathrm{m}$ CVI cut-point sampling period with liquid droplets, as discussed below. For this particular particle, $\mathrm{Ca}, \mathrm{K}, \mathrm{COOH}$ a)
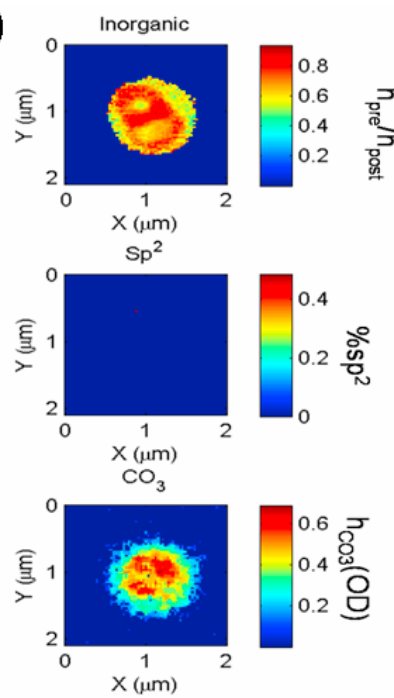
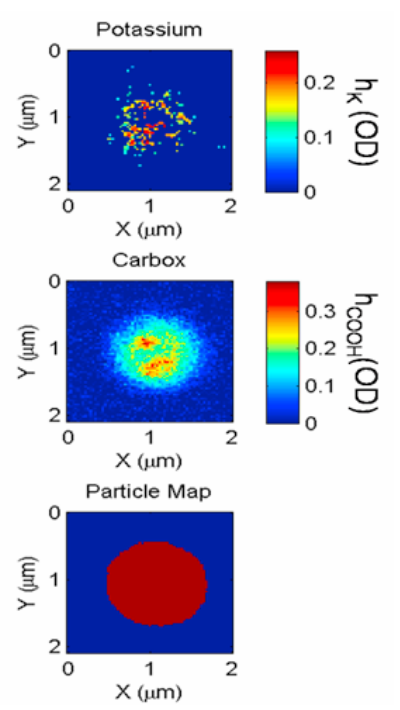

b)

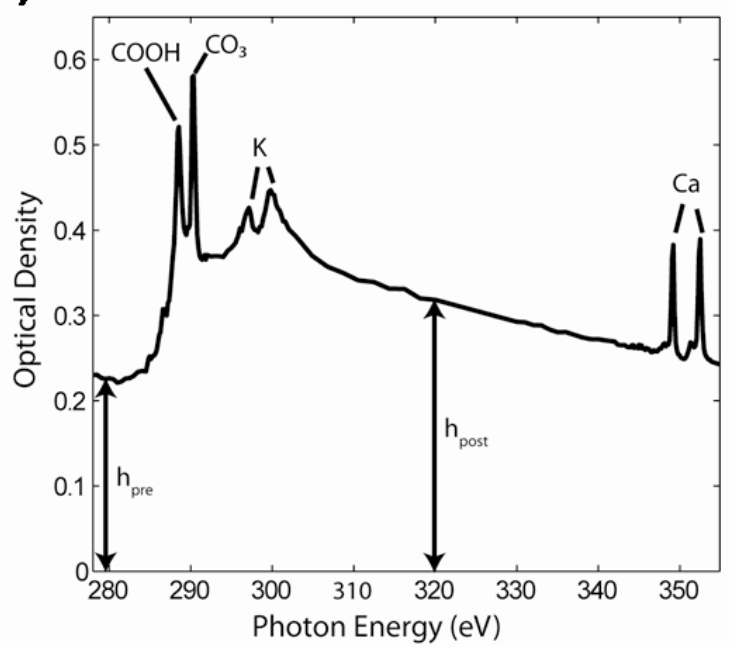

Figure 3. (a) STXM/NEXAFS maps of inorganic, potassium, $\mathrm{sp}^{2}$ bonds, $\mathrm{COOH}$ and $\mathrm{CO}_{3}$ for a single residue of a cloud droplet $(>19 \mu \mathrm{m})$. (b) STXM/NEXAFS spectrum over the area of the individual cloud droplet residue shown in Figure 3a. 


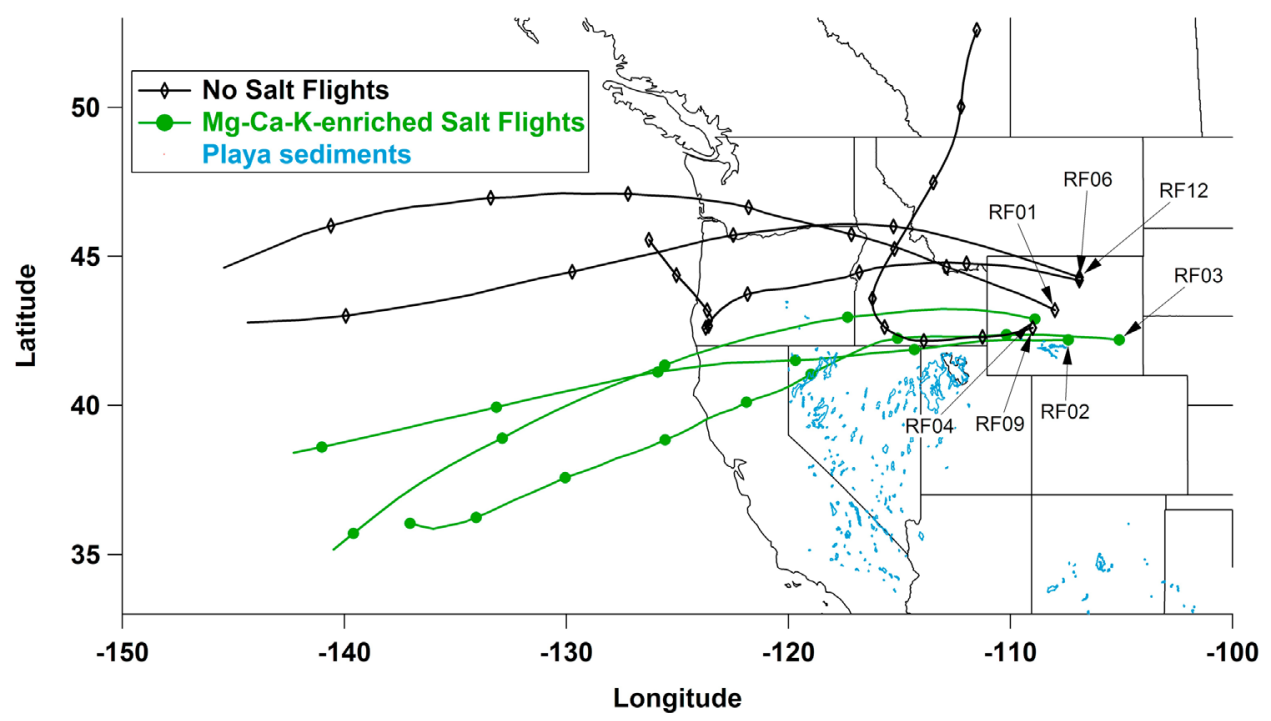

Figure 4. HYSPLIT air mass back trajectories (up to $48 \mathrm{~h}$, with dots shown every $6 \mathrm{~h}$ ) for ICE-L orographic wave cloud flights, classified as either having $\mathrm{Na}-\mathrm{Mg}-\mathrm{Ca}-\mathrm{K}-\mathrm{Cl}$ salts present (green) or not (black). For reference, a map of playa sediments [Soller and Reheis, 2004] is shown.

groups, and $\mathrm{CO}_{3}$ are all internally mixed. As discussed above, $\mathrm{Ca}, \mathrm{K}$, and carbonate are common components of playa evaporite minerals. Based upon STXM/NEXAFS analysis, the "haloes" observed by STEM-EDX were likely from an oxidized organic coating, presumably from cloud processing [Chen et al., 2007]. This is further confirmed by an elevated $\mathrm{C}$-ToF-AMS $\mathrm{O} / \mathrm{C}$ ratio $(0.84 \pm 0.36)$, indicative of oxygenated organic species [Aiken et al., 2008] present during cloud droplet residue sampling. Indeed, the AATOFMS observed ion peaks of possible organic acids, including $\mathrm{m} / \mathrm{z}-43\left(\mathrm{CH}_{3} \mathrm{COH}^{-} / \mathrm{HCNO}^{-}\right), \quad-73\left(\mathrm{C}_{2} \mathrm{HO}_{3}^{-}\right.$, glyoxylic acid), $-159\left(\mathrm{C}_{7} \mathrm{H}_{11} \mathrm{O}_{4}^{-}\right.$, pimelic acid), and -173 $\left(\mathrm{C}_{8} \mathrm{H}_{13} \mathrm{O}_{4}^{-}\right.$, suberic acid), within the mass spectral signatures of the playa salt cloud droplet residues.

[24] Overall, the ICE-L chemical signatures observed for the individual playa salt particles are consistent with previous measurements of playa dust. For dust from Lake Ebinur (China) and Owens Lake (CA), playa dust was found to be $\sim 10-30 \%$ soluble salts, predominantly sodium, calcium, and magnesium chloride and sulfate [Abuduwaili et al., 2008; Reheis, 1997; Reheis and Kihl, 1995]. Daily carbonate and total salt fluxes were found to be correlated with typical carbonate mass fractions of up to $\sim 25 \%$ [Reheis, 1997]. Compared to playa sediments, increased fractions of soluble salts and carbonate have been observed in the playa crustal dust from Owens Lake [Reheis, 1997]. Further, playa dust has been found to be up to $\sim 30 \%$ organic matter by mass [Reheis, 1997].

[25] While our focus is on RF03, sodium chloride salts enriched in $\mathrm{Mg}, \mathrm{Ca}$, and $\mathrm{K}$ were observed during three of seven ICE-L orographic wave cloud flights (Figure 4). Examination of HYSPLIT (Draxler and Rolph, NOAA Web site, 2003) air mass back trajectories for the $\mathrm{Mg}-\mathrm{Ca}-$ K-enriched salt flights (RF02, RF03, RF04) show transport over the northern edge of the Great Basin region of Nevada and Utah, the largest dust source region in the U.S. [Prospero et al., 2002; Washington et al., 2003]. The Great Basin region, once the sites of Lake Lahontan and Lake
Bonneville during the Quaternary period, contains many playas [Güven and Kerr, 1966], as shown in Figure 4 [Soller and Reheis, 2004]. During flights in which these enriched salts were not observed (RF01, RF06, RF09, RF12), the air masses followed more northerly trajectories, over land where playas are not present in abundance. For the "salt" flights, air mass back trajectories show transport times of less than $18 \mathrm{~h}$ from northern Utah and Nevada. While the vertical profiles of these HYSPLIT back trajectories do not show transport within the boundary layer (transport $\sim 2-6 \mathrm{~km}$ above ground level (AGL)), previous measurements of playa dust storms have shown high wind speeds [Pelletier, 2006], rapid lofting to high altitudes ( $>2 \mathrm{~km} \mathrm{AGL)} \mathrm{[Cahill}$ et al., 1996; Reid et al., 1994], as well as associated longrange transport [Formenti et al., 2003]. Indeed, for RF03, HYSPLIT forward trajectories from both the Black Rock Desert in Nevada and the Bonneville Salt Flats in Utah show lofting to $>2 \mathrm{~km}$ AGL with transport to Wyoming, in agreement with instability above $\sim 2 \mathrm{~km}$ AMSL based on radiosonde data taken over Salt Lake City. Further, primarily southwesterly wind gusts of up to $18 \mathrm{~m} / \mathrm{s}$ were observed over northwestern Nevada with westerly wind gusts of up to $12 \mathrm{~m} / \mathrm{s}$ measured over northwestern Utah. For RF03, elevated mass concentrations of particulate matter less than $10 \mu \mathrm{m}$ or $2.5 \mu \mathrm{m}\left(\mathrm{PM}_{10}\right.$ and $\left.\mathrm{PM}_{2.5}\right)$ were observed in Salt Lake City and Logan City, UT on November 16, 2007. For example, at the Utah State Division of Air Quality North Salt Lake monitoring site in Salt Lake City, the $24 \mathrm{~h}$ $\mathrm{PM}_{10}$ mass concentration was $86 \mu \mathrm{g} / \mathrm{m}^{3}$ on Nov. 16 , compared to the month average of $44 \mu \mathrm{g} / \mathrm{m}^{3}$ (standard deviation $(\sigma) 25 \mu \mathrm{g} / \mathrm{m}^{3}$ ). Likewise, at the Rose Park monitoring site in Salt Lake City, the $24 \mathrm{~h} \mathrm{PM}_{2.5}$ mass concentration was $30.3 \mu \mathrm{g} / \mathrm{m}^{3}$ on Nov. 16 , compared to the month average of $13.5 \mu \mathrm{g} / \mathrm{m}^{3}\left(\sigma 7.3 \mu \mathrm{g} / \mathrm{m}^{3}\right)$. While the exact playa source(s) could not be identified, together these trajectories and PM observations further support the detection of playa salts from the Great Basin region. 


\subsection{Supercooled Liquid Droplets}

[26] To evaluate the ability of playa salts to act as $\mathrm{CCN}$, the chemistry and CCN ability of Owens (dry) Lake crust was evaluated in the laboratory. Having a similar AATOFMS mass spectral signature to the cloud residue salts, the Owens (dry) Lake crust had an elevated CCN activity (high hygroscopicity) $(\kappa=0.84 \pm 0.10)$ compared to that measured previously by Koehler et al. [2009] for most mineral dust $(\kappa \leq 0.08)$. Previous CCN measurements of dry-generated $200 \mathrm{~nm}$ Owens Lake dust found $35 \%$ of the particles to have a $\kappa$ of 0.69 with $65 \%$ having a $\kappa$ of 0.05 ; particles $<100 \mathrm{~nm}$ were more $\mathrm{CCN}$-active with $\kappa$ values up to 1.07 [Koehler et al., 2007]. For comparison, highly CCNactive particles are considered to be those with $\kappa$ values between 0.5 and 1.4 [Petters and Kreidenweis, 2007]. $\mathrm{NaCl}$ has a $\kappa$ of 1.12-1.28 [Petters and Kreidenweis, 2007]; as a pure salt, it is slightly more hygroscopic than sea salt [Niedermeier et al., 2008], showing that playa salts can have CCN activities similar to those of sea salt. Magnesium chloride and calcium chloride, enriched in playa salts compared to sea salt, have significantly lower deliquescence relative humidities (DRHs) $\left(\mathrm{MgCl}_{2} \cdot 6 \mathrm{H}_{2} \mathrm{O}, 33 \% ; \mathrm{CaCl}_{2}\right.$. $6 \mathrm{H}_{2} \mathrm{O}, 28.3 \%$ ) compared to sodium chloride ( $\left.\mathrm{NaCl}, 75.3 \%\right)$ [Tang et al., 1997] with mixtures of these salts having even lower mutual DRHs [Kelly and Wexler, 2006]. In addition, the internal mixing of oxidized organics with salts is suggested to enhance water uptake at low relative humidities [Hersey et al., 2009], as well as to reduce or eliminate clear deliquescent phase transitions compared to those expected for inorganics only [Carrico et al., 2008]. Thus, it is likely that hygroscopic playa salts, observed as dry cloud residues, retained water under clear air conditions (average relative humidity of $42 \%(\sigma 29 \%))$.

[27] To further understand the activation of the supercooled liquid droplets observed within the orographic wave clouds during RF03, the maximum cloud supersaturation was modeled using the 1-D parcel model described by Heymsfield et al. [1991]. Using the average temperature $\left(-21.8^{\circ} \mathrm{C}\right)$, pressure (333 Torr), and altitude $(6573 \mathrm{~m})$ with a peak updraft velocity of $2.6 \mathrm{~m} / \mathrm{s}$ of the first (and lowest altitude) liquid phase cloud pass, the maximum supersaturation was estimated to be up to $\sim 8 \%$, similar to previous observations of supercooled liquid wave clouds [Heymsfield and Miloshevich, 1993]. While $8 \%$ supersaturation may be an overestimate, supersaturations reach very high levels because the droplet growth rates, which deplete the buildup of supersaturation, are relatively low at a temperature of $-20^{\circ} \mathrm{C}$ [Heymsfield and Miloshevich, 1993]. Collision-coalescence was not observed to occur in the model for the given microphysical constraints and timescale of the cloud parcels; similarly, CPI, radar, and lidar data showed no evidence of drizzle formation. Thus, in contrast to the warm clouds observed by Rudich et al. [2002], the playa salts were not able to or observed to initiate a precipitation mode during RF03. To examine the particles activated as cloud droplets during RF03, measured clear air particle and cloud droplet number concentrations were compared. During the clear air measurement periods $\left(\theta_{\mathrm{e}}=318.3-323.8 \mathrm{~K}\right)$, number concentrations of particles $0.1-1.0 \mu \mathrm{m}$ in diameter, measured by an UHSAS, averaged $25 \mathrm{~cm}^{-3}$ (maximum $164 \mathrm{~cm}^{-3}$ ) with average $\mathrm{CN}$ concentrations of $217 \mathrm{~cm}^{-3}$ (maximum $704 \mathrm{~cm}^{-3}$ ). During liquid-only sampling, average cloud droplet number concentrations, as measured by the CDP, were $64 \mathrm{~cm}^{-3}$ (maximum $125 \mathrm{~cm}^{-3}$ ) with an average of $88 \%(\sigma 40 \%)$ of droplets larger than $7 \mu \mathrm{m}$.

[28] To examine the variation of aerosol chemistry with cloud droplet diameter, CVI sampling was completed at two different CVI cut-points (7 $\mu \mathrm{m}$ and $19 \mu \mathrm{m})$. Sampling of cloud droplets $>7 \mu \mathrm{m}$ was completed at altitudes of 6.6 $7.7 \mathrm{~km}$ and ambient temperatures of -21 to $-32^{\circ} \mathrm{C}$; sampling of cloud droplets $>19 \mu \mathrm{m}$ was completed at $7.2 \mathrm{~km}$ and -26 to $-27^{\circ} \mathrm{C}$. Average cloud droplet size distributions during these two periods are shown in Figure 5; residue chemistry, as measured by the A-ATOFMS and C-ToF-AMS are also shown. During the $>19 \mu \mathrm{m}$ period, the average cloud droplet number concentration, measured by the CDP, was $66 \mathrm{~cm}^{-3}$ (maximum $125 \mathrm{~cm}^{-3}$ ) with a small contribution of cloud ice particles $(>50 \mu \mathrm{m})$ of $2 \mathrm{~L}^{-1}$ on average (maximum of $18 \mathrm{~L}^{-1}$ ) measured by the $2 \mathrm{DC}$ probe; $35 \%$ ( $\sigma 18 \%)$ of droplets were larger than $19 \mu \mathrm{m}$. As shown in Figures $5 \mathrm{~b}$ and $5 \mathrm{e}$, the playa salts were preferentially found in larger cloud droplets with the number fraction increasing from $57 \pm 10 \%$ to $90 \pm 6 \%$ with the increase in CVI cut-point. For residues of the larger cloud droplets, STXM/NEXAFS analysis classified all measured particles as internally mixed organic carbon and inorganic components, with $\sim 71 \%$ by number mixed with carbonate and $\sim 29 \%$ mixed with potassium as well (Table 2 ). Concurrent with the increase in the fraction of playa salts, the C-ToF-AMS non-refractory mass fractions showed an increase in organics $(37 \pm 17 \%$ to $80 \pm 4 \%$ ) and decrease in sulfate and ammonium (Figure 5); as shown by the A-ATOFMS mass spectra and confirmed with STXM/ NEXAFS, the majority of the organics measured by the C-ToF-AMS were internally mixed with the playa salts. Although within uncertainties, the C-ToF-AMS observed a higher $\mathrm{O} / \mathrm{C}$ ratio [Aiken et al., 2008] for the organic species observed during the $>19 \mu \mathrm{m}$ cloud droplet residue sampling than during the $>7 \mu \mathrm{m}$ sampling $(1.19 \pm 0.15$ versus $0.84 \pm$ 0.36 , respectively), suggesting that the larger cloud droplets may have undergone additional cloud processing during transport. In addition to the probable organic acids (glyoxylic, pimelic and suberic acid) observed by the A-ATOFMS to be internally mixed with the $>7 \mu \mathrm{m}$ cloud droplet playa salt residues, additional ion peaks of potential organic acids were observed for the $>19 \mu \mathrm{m}$ cloud droplet playa salt residues: $m / z-45$ ( $\mathrm{HCOO}^{-}$, formic acid), $-87\left(\mathrm{C}_{3} \mathrm{H}_{3} \mathrm{O}_{3}^{-}\right.$, pyruvic acid), and $-103\left(\mathrm{C}_{3} \mathrm{H}_{3} \mathrm{O}_{4}^{-}\right.$, malonic acid) [Sullivan and Prather, 2007]. Considering the oxidation pathways of organic gas phase species, oxalic, glutaric, adipic, and pyruvic acids have previously been suggested as the primary contributors to organic mass production during aqueous phase processing [Ervens et al., 2004]. The $\mathrm{O} / \mathrm{C}$ ratio observed by the C-ToF-AMS during $>19 \mu \mathrm{m}$ sampling is among the highest reported, significantly above reported values for laboratory secondary organic aerosol [e.g., Aiken et al., 2008; Hildebrandt et al., 2009], highlighting the need to further understand cloud processing of organics. Previously, Sun et al. [2009] observed an O/C ratio of 1.08 for organic aerosol, hypothesized to have undergone aqueous phase processing during transport over the Pacific Ocean to Whistler Mountain (Canada).

[29] While organics are generally considered to be less efficient CCN than most inorganic species, small amounts of 


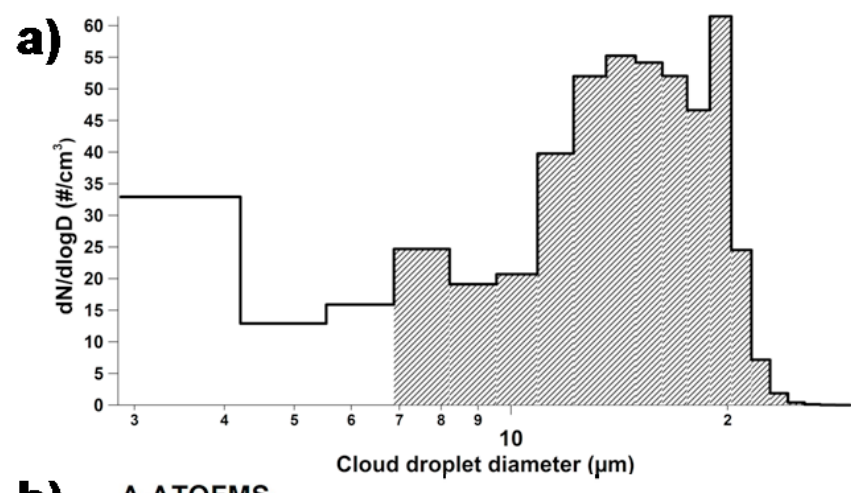

b)
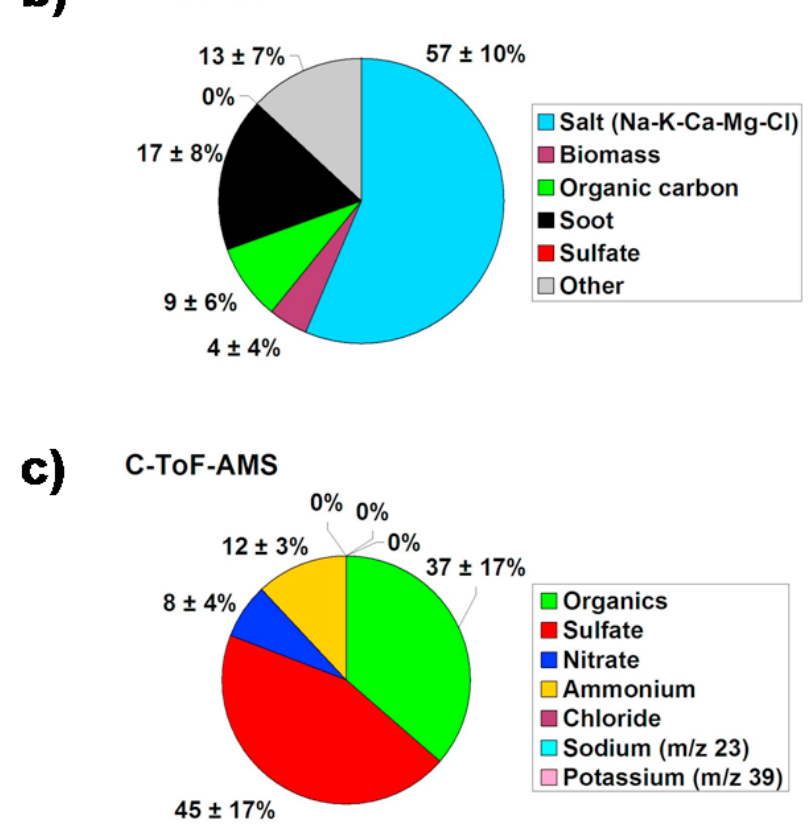

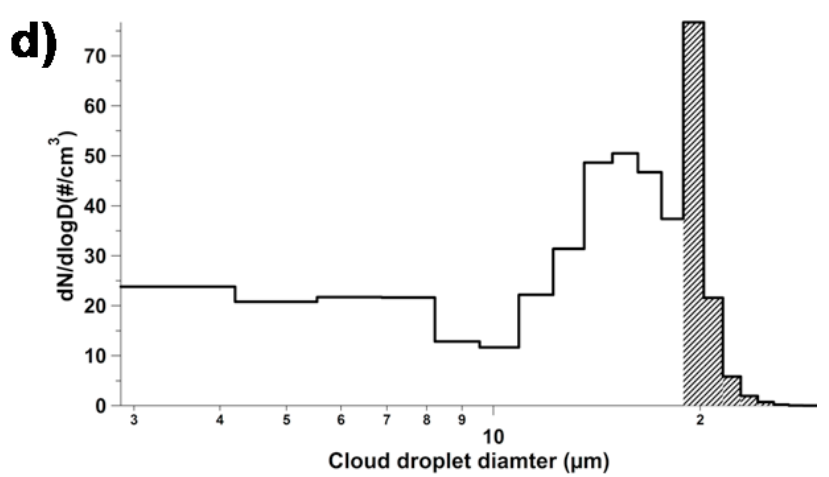

e) A-ATOFMS

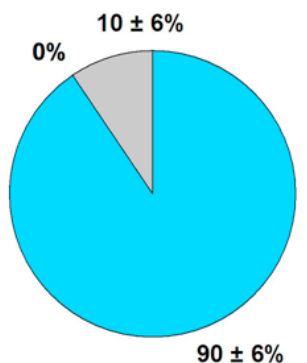

$\square$ Salt (Na-K-Ca-Mg-Cl)

$\square$ Biomass $\square$ Organic carbon

- Soot

Sulfate

$\square$ Other

f)

\section{C-ToF-AMS}

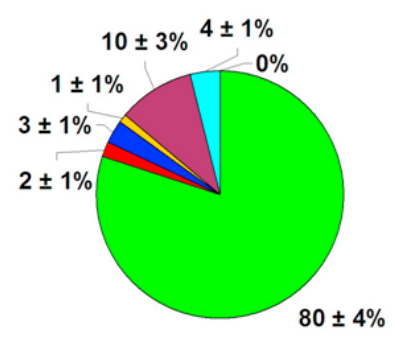

口Organics

- Sulfate

- Nitrate

$\square$ Ammonium

a Chloride

$\square$ Sodium $(\mathrm{m} / \mathrm{z} 23)$

Potassium (m/z 39)

Figure 5. Average cloud droplet size distributions, measured by the CDP, are shown for the CVI sampling periods corresponding to cloud droplet cut-points of (a) $>7 \mu \mathrm{m}$ and (d) $>19 \mu \mathrm{m}$. Shaded areas represent the cloud droplet diameters sampled by the A-ATOFMS and C-ToF-AMS during each sampling condition. Number fractions of particle types measured by the A-ATOFMS for residues of cloud droplets (b) $>7 \mu \mathrm{m}$ and (e) $>19 \mu \mathrm{m} ; 23$ and 21 particles were chemically analyzed by A-ATOFMS for these two periods, respectively. Non-refractory mass fractions measured by the C-ToF-AMS for residues of cloud droplets (c) $>7 \mu \mathrm{m}$ and (f) $>19 \mu \mathrm{m}$. While C-ToF-AMS ion peaks at $\mathrm{m} / z 23$ and 39 are not quantitative measures of $\mathrm{Na}$ and $\mathrm{K}$, they indicate the presence of these species; all other species mass fractions are quantitative.

salt $(<5 \%$ of dry mass for $\mathrm{NaCl})$ have been found to greatly decrease the $\mathrm{S}_{\mathrm{c}}$ of even slightly soluble organic compounds [Bilde and Svenningsson, 2004]. At the vaporization temperature utilized by the C-ToF-AMS during ICE-L (550$560^{\circ} \mathrm{C}$ ), the C-ToF-AMS is unable to efficiently detect refractory species present in sea salt (e.g., $\mathrm{NaCl}$ ); however, due to the low ionization potentials of $\mathrm{Na}$ and $\mathrm{K}$, a small fraction of the salts may undergo surface ionization [Allan et al., 2004]. Through comparison of the C-ToF-AMS nonrefractory mass concentrations with residue volume concentrations measured by the CVI OPC (and assuming a density of $1.7 \mathrm{~g} \mathrm{~cm}^{-3}$ ), it is estimated that a significant fraction of the particle mass was likely refractory during both the $>7$ and $>19 \mu \mathrm{m}$ periods, respectively; this refractory mass was not detected by the C-ToF-AMS. However,
Table 2. STXM/NEXAFS Individual Particle Classifications ${ }^{\mathrm{a}}$

\begin{tabular}{lccc}
\hline Type & $>19 \mu \mathrm{m}$ Liquid & Ice $(>7 \mu \mathrm{m})$ & Clear Air \\
\hline OC & 0 & 2 & 1 \\
OCEC & 0 & 1 & 0 \\
OCECIn & 0 & 0 & 1 \\
OCIn & $17,\left(12 \mathrm{CO}_{3}\right),(5 \mathrm{~K})$ & $6,\left(6 \mathrm{CO}_{3}\right),(3 \mathrm{~K})$ & $7,\left(2 \mathrm{CO}_{3}\right),(1 \mathrm{~K})$ \\
\hline
\end{tabular}

${ }^{\mathrm{a}}$ Numbers in the table represent the number of particles in each sample that contained specified particle type: organic carbon (OC), organic carbon-elemental carbon (OCEC), organic carbon-elemental carboninorganic (OCECIn), and organic carbon-inorganic (OCIn). The numbers of particles found to have $\mathrm{CO}_{3}$ and/or $\mathrm{K}$ are shown in parentheses. For the three sample periods ( $>19 \mu \mathrm{m}$ liquid, ice, and clear air), the total numbers of particles analyzed were 9,9 , and 17 , respectively. 

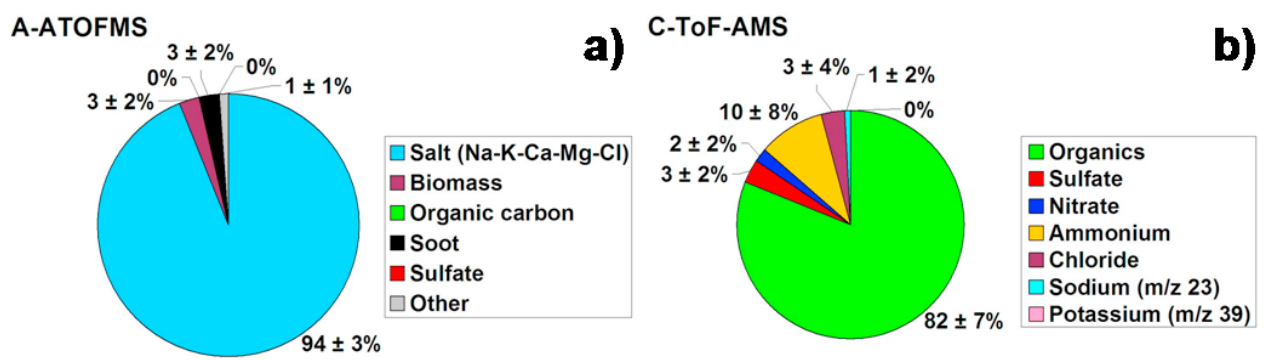

Figure 6. (a) Number fractions of particle types measured by the A-ATOFMS for residues of cloud ice $>7 \mu \mathrm{m} ; 80$ particles were chemically analyzed; $78 \%$ of the salts were observed to be internally mixed with organics. (b) Non-refractory mass fractions measured by the C-ToF-AMS for residues of cloud ice $>7 \mu \mathrm{m}$.

qualitatively, the C-ToF-AMS observed higher $\mathrm{Na}, \mathrm{K}$, and $\mathrm{Cl}$ signals in the larger cloud droplets, in agreement with the enrichment of playa salts in the larger cloud droplets, as measured by the A-ATOFMS.

[30] The observed enrichment of playa salts in the larger cloud droplets is consistent with the relationship between cloud droplet size and $\mathrm{S}_{\mathrm{c}}$ with the largest drops forming on the largest, most hygroscopic CCN [Hudson and Rogers, 1986]. Twohy et al. [1989] used a parcel model to predict size-dependent droplet chemistry for an ammonium sulfate small aerosol mode and a sea salt large aerosol mode; similar to that observed herein, sea salt was calculated to be within the largest droplets, showing that bulk droplet composition does not represent the composition of individual cloud droplets. For coastal stratus clouds heavily influenced by sea salt, Munger et al. [1989] observed higher $\mathrm{Na}^{+}, \mathrm{Ca}^{2+}$, and $\mathrm{Mg}^{2+}$ concentrations in larger droplets with higher concentrations of $\mathrm{SO}_{4}^{2-}, \mathrm{NO}_{3}^{-}, \mathrm{NH}_{4}^{+}$, and $\mathrm{H}^{+}$in smaller droplets, similar to that observed for the RF03 residues. It is predicted that cloud drops will retain the size-resolved chemistry of the original $\mathrm{CCN}$ until coalescence produces drizzle-sized drops [Ogren and Charlson, 1992]. Previously, giant aerosol particles primarily consisting of $\mathrm{NaCl}$, observed over the eastern Great Lakes region of the United States and Canada, were found to contribute to the presence of supercooled large drops [Lasher-Trapp et al., 2008]. In addition, satellite measurements showed that playa dust from the Aral Sea region increased cloud drop size and promoted precipitation [Rudich et al., 2002]. For particle sizes similar to large mineral dust [Patterson and Gillette, 1977; Reid et al., 1994], playa salts can serve as giant CCN [Andreae and Rosenfeld, 2008], increasing cloud droplet size similar to large hygroscopic salts used in cloud seeding studies [Drofa, 2006; Ghate et al., 2007].

\subsection{Cloud Ice Residues}

[31] During sampling in cloud ice regions, the 2DC probe concentrations averaged $57 \mathrm{~L}^{-1}\left(\sigma 113 \mathrm{~L}^{-1}\right)$ with sampling at $6.5-7.7 \mathrm{~km}$. Although flight level temperatures ranged from -21 to $-31^{\circ} \mathrm{C}$, the wave cloud tops reached below $-38^{\circ} \mathrm{C}$, resulting in influence from homogeneous freezing (P. R. Field et al., Contrasting ice nucleation in two lee wave clouds observed during the ICE-L campaign, manuscript in preparation, 2010), discussed below. Similar to the $>19 \mu \mathrm{m}$ droplet residues, the ice residues were dominated by playa salts internally mixed with organics, as shown in Figure 6.
This was further confirmed by STXM/NEXAFS analysis, which showed that 6 out of the 9 analyzed ice residues were internally mixed organics and inorganics (Table 2). AATOFMS results showed that approximately half as many ice salt residues were internally mixed with sulfate and/or nitrate $(28 \pm 5 \%)$ compared to the cloud droplet salt residues $(69 \pm 13 \%)$ (Figure 7). This is consistent with lower mass fractions of sulfate and nitrate measured by the C-ToF-AMS for the ice residues compared to the cloud droplet residues (Figures 5 and 6). Similarly, Cziczo et al. [2004] observed large, unreacted sea salt particles as residues of cirrus ice produced by homogeneous freezing. It was hypothesized that the preferential freezing of sea salt was due to the extensive water uptake of $\mathrm{NaCl}$, resulting in larger, more dilute, sea salt particles which were more likely to freeze compared to the smaller, more numerous sulfate/K/organic/ nitrate particles observed in the clear air [Cziczo et al., 2004]. Similarly, organic carbon/sulfate particles were not observed by the A-ATOFMS for the RF03 ice residues. Similar to the $>19 \mu \mathrm{m}$ cloud droplet residues, the O/C ratio observed by the C-ToF-AMS during ice residue sampling was elevated $(1.15 \pm 0.25)$, indicative of highly oxygenated organic aerosol [Aiken et al., 2008]. In addition to the probable organic acid ion peaks observed during cloud droplet residue sampling, oxalic acid $\left(m / z-89\left(\mathrm{C}_{2} \mathrm{HO}_{4}^{-}\right)\right.$and $\left.m / z-179\left(\left(\mathrm{C}_{2} \mathrm{O}_{4} \mathrm{H}\right)_{2} \mathrm{H}^{-}\right)\right)$[Sullivan and Prather, 2007] was observed to be preferentially mixed with the playa salt ice residues.

[32] Despite sampling at temperatures above $-31^{\circ} \mathrm{C}$, the wave cloud tops reached below $-38^{\circ} \mathrm{C}$ as confirmed by the radar signature and a kinematic 1-D model (Field et al., manuscript in preparation, 2010). This temperature would allow homogeneous freezing to occur in dilute solution droplets and activated cloud droplets [DeMott and Rogers, 1990], as confirmed by the radar signature and a kinematic 1-D model (Field et al., manuscript in preparation, 2010). During RF03, homogeneously nucleated ice particles were observed to fall from above the sampling altitude, as well as follow the wave cloud streamlines to a lower altitude; this ice greatly influenced the sampled ice residues (Field et al., manuscript in preparation, 2010), suggesting that the majority of the ice playa salt residues were homogeneously frozen at higher altitudes, similar to the ice sea salt residues observed by Cziczo et al. [2004] and Twohy and Poellot [2005]. In warmer mixed-phase cloud regions, riming, as indicated in CPI images (not shown), would have 


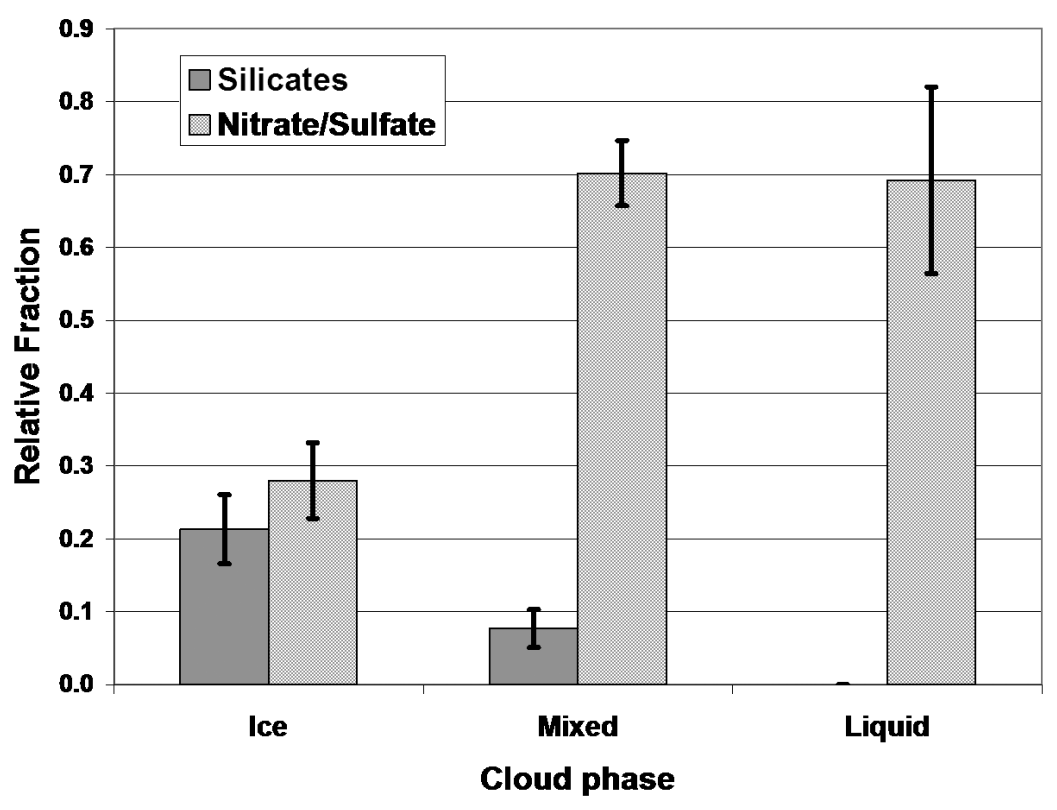

Figure 7. Number fractions of cloud residues identified as salts, measured by the A-ATOFMS, found to be internally mixed with silicates or nitrate and/or sulfate; 75, 104, and 13 salt particles, respectively, were chemically analyzed for the three cloud periods.

contributed additional soluble salts to the ice. However, in addition to homogeneous freezing, the Field et al. (manuscript in preparation, 2010) model also indicated a small contribution $\left(\sim 6 \mathrm{~L}^{-1}\right.$ to the total ice particle concentration of $\sim 50 \mathrm{~L}^{-1}$ ) of heterogeneous condensation/immersion freezing. This is consistent with a maximum ice nuclei concentration of $3 \mathrm{~L}^{-1}$ measured by the CFDC operating at $-31^{\circ} \mathrm{C}$ and a supersaturation (with respect to water) of up to $1 \%$, for the ice residues. For previous marine anvil cirrus ice measurements by the CFDC, a small fraction of the salts were found to act as ice nuclei, freezing below water saturation [Prenni et al., 2007]. Less hygroscopic playa dust has been shown to nucleate ice heterogeneously at lower relative humidities than required for homogeneous freezing of aqueous particles at temperatures less than $-40^{\circ} \mathrm{C}$; smaller contributions to heterogeneous ice formation from about -37 to $-40^{\circ} \mathrm{C}$ were also observed [Koehler et al., 2007]. However, the study by Koehler et al. [2007] did not report ice formation for activated fractions of $<1 \%$ or examine playa dust greater than $400 \mathrm{~nm}$ in size, so potential heterogeneous ice formation by small fractions of particles at temperatures above about $-37^{\circ} \mathrm{C}$ were not resolved. For the RF03 ice salt residues, $21 \pm 5 \%$ were found to contain silicates ( $20 \pm 4 \%$ of the total ice residues), while none of the cloud droplet salt residues contained silicates. We can assume that $\sim 2-3 \%$ of these "dust-like" playa salts may activate as ice nuclei [Field et al., 2006; Prenni et al., 2009]. Considering the concentration of residues measured by the CVI OPC, we estimate that an average of 2.9-4.4 $\mathrm{L}^{-1}$ (range of 1.1-8.0 $\mathrm{L}^{-1}$ given uncertainties) playa dust may have been IN active. This estimate is in excellent agreement with the modeled $\left(\sim 6 \mathrm{~L}^{-1}\right)$ and measured IN concentrations (maximum $3 \mathrm{~L}^{-1}$, average $1.0 \mathrm{~L}^{-1}, \sigma 0.7 \mathrm{~L}^{-1}$ ), suggesting that the silicate-containing playa salts may have served as heterogeneous ice nuclei. Further, during sampling regions con- taining only cloud droplets, IN concentrations were below the detection limit $\left(0.1 \mathrm{~L}^{-1}\right)$ of the CFDC, consistent with the relatively low abundance of silicate-containing particles present.

[33] It should be noted that during cloud ice sampling, a significant fraction $(35 \pm 5 \%)$ of the total ice residue AATOFMS mass spectra also contained markers of inlet metals, such as chromium $\left(\mathrm{m} / z 52, \mathrm{Cr}^{+}\right)$, manganese $(\mathrm{m} / \mathrm{z} 55$, $\left.\mathrm{Mn}^{+}\right)$, iron $\left(m / z 56, \mathrm{Fe}^{+}\right)$, and molybdenum $\left(m / z 98, \mathrm{Mo}^{+}\right)$, indicating that a fraction of the ice particles impacted the stainless steel CVI aircraft inlet during sampling, as previously observed in even higher concentrations by Murphy et al. [2004], likely due to higher aircraft speeds. Indeed, a greater concentration ( $\sim 50$ times) of ice residues $>110 \mathrm{~nm}$, was measured by the CVI OPC compared to ice crystal concentrations, as measured by the $2 \mathrm{DC}$, further indicating the occurrence of ice crystal shattering within the CVI inlet, as well as possible residue multiplication due to dissolved salts within homogeneously frozen ice crystals. However, while a fraction of the positive ion mass spectra were influenced by these metals, the distinguishing positive ion mass spectral signature of the playa salt (i.e., $\mathrm{Na}, \mathrm{K}, \mathrm{Mg}, \mathrm{Ca}$ ) was still present, allowing the residues to be classified as salts. Further, the negative ion mass spectra of these particles were identical to salt particles that had not collided with the inlet (i.e., did not contain $\mathrm{Cr}, \mathrm{Mn}, \mathrm{Fe}, \mathrm{Mo}$ ), showing how the dual-polarity mass spectrometer of the A-ATOFMS can help distinguish the source signature of the residue despite interferences from the inlet metals. Although inlet metals were only observed during ice-containing sampling periods, no correlation was observed between ice particle size (or riming) and the presence of inlet metals in the A-ATOFMS mass spectra. Further, ice nuclei concentrations measured within clouds behind the CVI during ICE-L did not generally seem enhanced relative to IN concentrations measured 


\section{Mixed-Phase Cloud}

\section{A-ATOFMS}

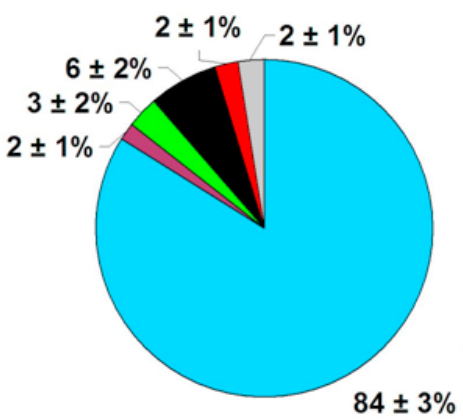

a)

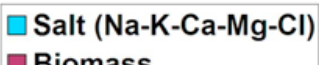

- Biomass

$\square$ Organic carbon

- Soot

- Sulfate

$\square$ Other

\section{Clear Air}

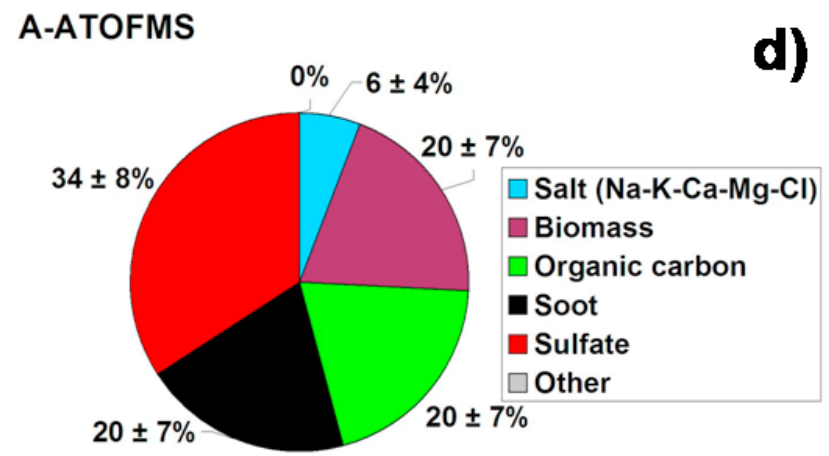

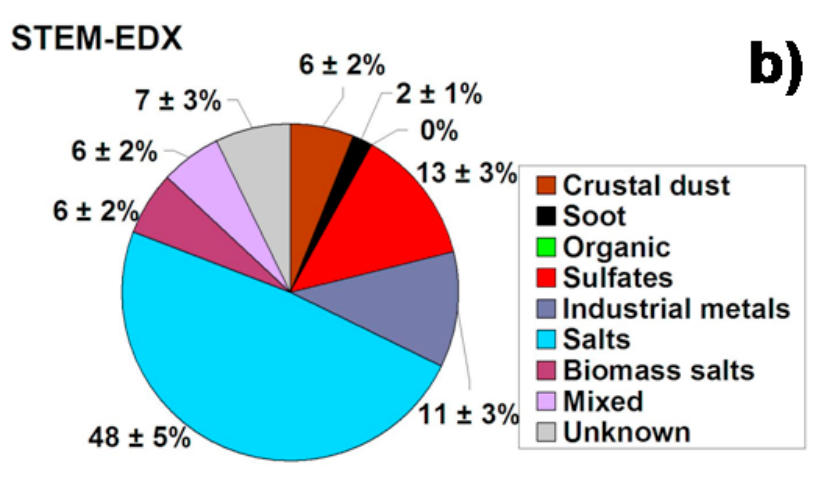

STEM-EDX

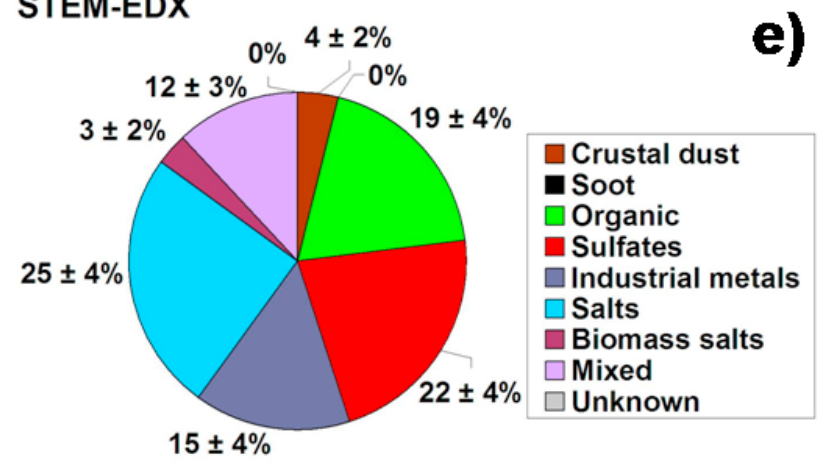

\section{C-ToF-AMS}

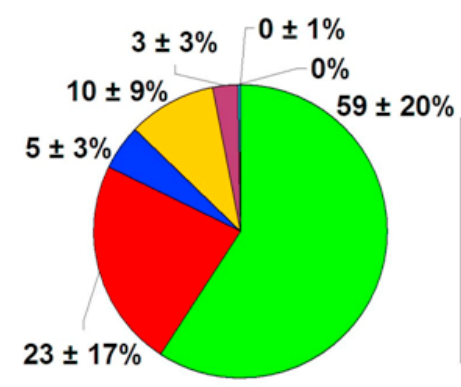

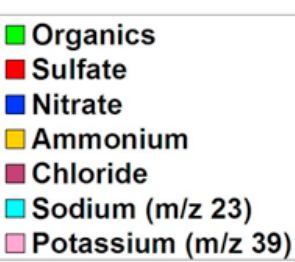

C-ToF-AMS

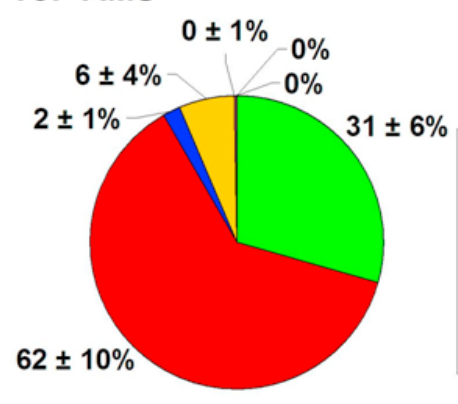

f)

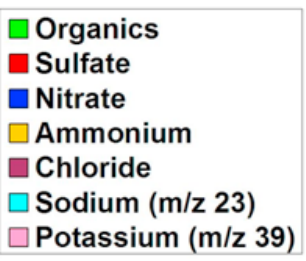

Figure 8. Number fractions of particle types measured by the (a, d) A-ATOFMS and (b, e) STEM-EDX for mixed phase cloud residues and clear air particles, respectively. For mixed phase and clear air sampling, 124 and 35 particles, respectively, were chemically analyzed by the A-ATOFMS. For the STEM-EDX small impactor stage $\left(d_{g} \sim 0.08-0.42 \mu \mathrm{m}\right), 101$ and 102 particles were chemically analyzed for the mixed phase and clear air periods, respectively. Relative non-refractory mass fractions measured by the C-ToF-AMS for (c) mixed phase cloud residues and (f) clear air particles.

in ambient air at similar processing conditions (Field et al., manuscript in preparation, 2010).

\subsection{Mixed Phase Cloud Residues}

[34] Concurrent CVI sampling by the A-ATOFMS, CToF-AMS, and impactor for STEM-EDX analysis was conducted for mixed phase (coexisting supercooled liquid droplets and ice particles) cloud residues, allowing a comparison of the three aerosol chemical analysis techniques
(Figure 8). During mixed phase sampling $\left(-20\right.$ to $-32^{\circ} \mathrm{C}$, $6.4-7.9 \mathrm{~km}$ ), supercooled droplets, measured by the CDP, were present at an average of $44 \mathrm{~cm}^{-3}$ (maximum $144 \mathrm{~cm}^{-3}$ ); cloud ice particles, measured by the 2DC probe, were present at an average of $10 \mathrm{~L}^{-1}\left(\sigma 14 \mathrm{~L}^{-1}\right)$. The relative contribution of the ice particles to the mixed phase residue number is expected to be enhanced since residue multiplication can occur from ice particles larger than $\sim 75 \mu \mathrm{m}$ (aerodynamic diameter) that may break up within the CVI 
inlet [Twohy et al., 2003], although residue mass will be unaffected. The number fraction of mixed-phase residues containing inlet metals, as measured by the A-ATOFMS, was minor $(4 \pm 2 \%)$. For the mixed-phase STEM-EDX sample, $3 \%$ of the small impactor stage residues and $7 \%$ of the large impactor stage residues contained stainless steel markers (not shown), in agreement with that observed by the A-ATOFMS. As expected for these mixed phase residues, the number fraction of playa salts $(84 \pm 3 \%)$, as measured by the A-ATOFMS, was between that of the droplet residues $(57 \pm 10 \%)$ and ice residues $(94 \pm 3 \%)$ (Figures 5, 6, and 8). Similarly, the organic mass fraction, as measured by the C-ToF-AMS, increased from droplets $(37 \pm 17 \%)$ to mixed phase $(59 \pm 20 \%)$ to ice $(82 \pm 7 \%)$, with a corresponding increase in the $\mathrm{O} / \mathrm{C}$ ratio $(0.84 \pm 0.36$ to $1.00 \pm 0.31$ to $1.15 \pm 0.25$, respectively). While the number fraction of salts containing sulfate and/or nitrate was similar for the mixed phase $(70 \pm 4 \%)$ and droplets $(69 \pm 13 \%)$ (Figure 7$)$, the mass fraction of sulfate in all residues decreased from droplets $(45 \pm 17 \%)$ to mixed phase $(23 \pm 17 \%)$ to ice $(3 \pm 2 \%)$. Comparison of the STEM-EDX small and large particle impactor stages showed the salts were enhanced in the large stage (74 $\pm 5 \%$, not shown) compared to the small stage $(48 \pm 5 \%)$, in agreement with the presence of large playa salts with a size distribution similar to that of mineral dust [Patterson and Gillette, 1977]. STEM-EDX showed a greater fraction of sulfate particles for the small stage $(13 \pm 3 \%)$ compared to the large stage ( $5 \pm 2 \%$, not shown).

[35] For comparison between STEM-EDX, A-ATOFMS, and $\mathrm{C}-\mathrm{ToF}-\mathrm{AMS}$, one must first consider the relationship between particle geometric diameter $\left(d_{g}\right)$, measured by STEM, and vacuum aerodynamic diameter $\left(d_{v a}\right)$, measured by the A-ATOFMS and C-ToF-AMS. For spherical particles with no voids, $d_{g}$ and $d_{v a}$ are related by the following equation:

$$
d_{v a}=d_{g} \frac{\rho_{p}}{\rho_{0}}
$$

where $\rho_{0}$ is the standard density $\left(1 \mathrm{~g} \mathrm{~cm}^{-3}\right)$ and $\rho_{p}$ is the average particle density for a multiple component particle [DeCarlo et al., 2004]. Thus, the size ranges of the AATOFMS and C-ToF-AMS are most similar to the small impactor stage, which collected approximately 0.08 to $0.42 \mu \mathrm{m}\left(d_{g}\right)$ or 0.136 to $0.714 \mu \mathrm{m}\left(d_{v a}\right)$ particles, compared to the large impactor stage $\left(>0.42 \mu \mathrm{m} d_{g}\right.$ or $\left.>0.714 \mu \mathrm{m} d_{v a}\right)$, given an assumed effective density of $\sim 1.7 \mathrm{~g} \mathrm{~m}^{-3}$ for the salt particles, as observed previously for ambient sea-salt particles at low relative humidity [Moffet et al., 2008b]. It also should be noted that the STEM-EDX sample was collected for a shorter time period than the A-ATOFMS and C-ToFAMS mixed phase residue samples, which may yield minor differences in the samples.

[36] Comparison of the number fractions of different particle types measured by the A-ATOFMS and STEM-EDX small impactor stage (Figures $8 \mathrm{a}$ and $8 \mathrm{~b}$ ) shows a smaller fraction of salts detected by STEM-EDX compared to the AATOFMS, although some of the salts are included in the STEM-EDX "mixed" particle category. In a previous comparison ATOFMS and SEM-EDX of K- and Na-containing particles in Mexico City, the ATOFMS observed twice as many particles containing $\mathrm{Cl}^{-}$compared to SEM-EDX due to the increased sensitivity of the ATOFMS to this species, as well as possible $\mathrm{Cl}^{-}$loss reactions following filter collection [Moffet et al., 2008a]. In agreement, the A-ATOFMS observed $6 \pm 2 \%$ of the mixed phase residues to be silicatecontaining salts, whereas STEM-EDX categorized $6 \pm 2 \%$ of the residues as crustal dust. The large fraction of industrial metals observed by STEM-EDX may have been above the $d_{v a}$ range of the A-ATOFMS due to high densities, accounting for this discrepancy between the two results. Last, STEM-EDX identified a greater fraction of sulfate particles compared to the A-ATOFMS $(13 \pm 3 \%$ versus $2 \pm$ $1 \%$, respectively); however, it is likely that a fraction of these particles were internally mixed with organic species and/or soot and, thus, were classified by the A-ATOFMS as such. Overall, A-ATOFMS and STEM-EDX were found to be in good agreement.

\subsection{Comparison to Clear Air}

[37] In the ambient air surrounding the orographic wave clouds, the A-ATOFMS observed the majority of submicron particles to be either externally mixed sulfate or an internal carbonaceous/sulfate mixture (biomass, organic carbon, and soot particle types), which is consistent with the majority of the non-refractory submicron mass being composed of organics and sulfate, as measured by the C-ToFAMS (Figure 8). Given the uncertainties associated with the observed low mass loadings, the C-ToF-AMS did not observe a significant difference in the mass fractions of organics, sulfate, nitrate, and ammonium between the ambient air and cloud droplet residues; similar $\mathrm{O} / \mathrm{C}$ ratios $(0.77 \pm 0.28$ versus $0.84 \pm 0.36)$ were observed for the organic aerosol as well. Relative to cloud sampling, externally mixed sulfate particles, measured by A-ATOFMS and STEM-EDX, were present in higher concentrations in the clear air. In addition, organics were enriched compared to sulfate (C-ToF-AMS) in the ice residues compared to the clear air, possibly due to the internal mixing of a fraction of the organics with playa salts, as confirmed by STXM/ NEXAFS analysis. A-ATOFMS and STEM-EDX results both show an enrichment of the playa salts by number in the cloud residues $\left(>\sim 80 \mathrm{~nm} d_{g}\right)$ compared to the clear air. Similar enrichments were observed by Cziczo et al. [2004], wherein $26 \%$ of homogeneously frozen ice residues were sea salt compared to $<1 \%$ outside of the cirrus; however, these anvil cirrus clouds were associated with convective systems which were hypothesized to transport sea salt from the surface. Twohy and Anderson [2008] observed similar enrichments of salts among $<0.2 \mu \mathrm{m}$ cloud droplet residues collected within eastern Pacific stratocumulus, Caribbean Sea small cumulus, and Indian Ocean small cumulus compared to ambient particles.

[38] As discussed in Section 3.2, average $\mathrm{CN}$ clear air concentrations were $217 \mathrm{~cm}^{-3}$ (maximum $704 \mathrm{~cm}^{-3}$ ) with average submicron $(0.1-1.0 \mu \mathrm{m})$ number concentrations of $25 \mathrm{~cm}^{-3}$ (maximum $164 \mathrm{~cm}^{-3}$ ); in comparison, cloud droplet number concentrations averaged $64 \mathrm{~cm}^{-3}$ (maximum $125 \mathrm{~cm}^{-3}$ ). This comparison suggests that most particles greater than $100 \mathrm{~nm}$, as well as a fraction of 13-100 nm particles, would be expected to serve as nuclei for cloud droplet formation. However, CVI cloud droplet residues $>110 \mathrm{~nm}$ in diameter had average number concentrations of only $3.3 \mathrm{~cm}^{-3}$ (maximum $6.9 \mathrm{~cm}^{-3}$ ), despite an average of 
$88 \%$ of droplets possessing diameters larger than $7 \mu \mathrm{m}$, as measured by the CDP. CVI concentrations were much greater for residues $<110 \mathrm{~nm}$ (average $21 \mathrm{~cm}^{-3}$, maximum $\left.47 \mathrm{~cm}^{-3}\right)$. Also, during liquid droplet $(>7 \mu \mathrm{m})$ sampling, the C-ToF-AMS measured an average non-refractory $\mathrm{PM}_{1}$ mass concentration of $0.035 \pm 0.006 \mu \mathrm{g} \mathrm{m}^{-3}$, which was only $13 \pm 5 \%$ of that observed for the clear air $(0.27 \pm$ $0.09 \mu \mathrm{g} \mathrm{m}^{-3}$ ). However, this particularly low fraction may be partially due to preferential activation of larger, more refractory salts (which are not efficiently detected by $\mathrm{C}-\mathrm{ToF}-$ AMS) compared to smaller organic-sulfate particles. Thus, it appears that all particles $>110 \mathrm{~nm}$ did not result in cloud droplets $>7 \mu \mathrm{m}$, suggesting that playa salts are preferentially activated over other particle types in this size range, as measured by A-ATOFMS and STEM-EDX.

\section{Conclusion}

[39] Playa salts, comprised of $\mathrm{Na}-\mathrm{K}-\mathrm{Mg}-\mathrm{Ca}-\mathrm{Cl}$ salts, internally mixed with oxidized organics, presumably produced by cloud processing, and carbonate have been shown to act as cloud nuclei in orographic wave clouds over Wyoming. Similar to previous observations of sea salt in marine environments, these playa salts were enhanced in larger droplets $(>19 \mu \mathrm{m})$ compared to smaller droplets $(>7 \mu \mathrm{m})$. Enhancement of the playa salts in ice, compared to the clear air and droplets, was also observed, due to influences of homogeneous freezing and riming. A small fraction of silicate-containing playa salts are hypothesized to be important in the heterogeneous ice nucleation observed in the wave clouds. The unique ability of the A-ATOFMS to distinguish between sea salt and playa salts was essential for the major findings of this study. Excellent agreement was achieved between the aerosol chemical analysis techniques used in this study (A-ATOFMS, C-ToF-AMS, STEM-EDX, STXM/NEXAFS). The techniques are complementary, combining together to provide unprecedented detail on single-particle mixing state with quantification of non-refractory particle components.

[40] Although the generation of wind-blown dust from playas is relatively well-known, the relative role of playa dust globally in cloud formation is highly uncertain. Previous laboratory studies of the $\mathrm{CCN}$ and IN abilities of playa dust have suggested their importance in cloud formation [Koehler et al., 2007]. Further, satellite-based studies of the dust storms from the Aral Sea suggested that playa salts promote precipitation and act as giant $\mathrm{CCN}$ [Rudich et al., 2002]; however, cloud residue analysis was not completed to confirm the chemistry and associated $\mathrm{CCN}$ activity of the observed dust. Thus, these ICE-L results represent the first direct detection of playa salts serving as cloud nuclei within clouds. Due to the global abundance of playas [Jones and Deocampo, 2004; Prospero et al., 2002] and increasing potential for playa dust storms due to land use changes [Gill, 1996], it is particularly important to understand the impact of playa dust on clouds. Based on the results shown herein, we suggest that playa salts impact cloud droplet and ice formation and cloud properties, particularly in remote continental locations. In-depth studies of the salt-producing potentials of playas globally are needed to further evaluate the transport, mixing, and cloud interactions of these salts in the global atmosphere. The implications of this study have ramifications for land use decisions and climate predictions, particularly of the indirect effect and regional weather patterns.

[41] Acknowledgments. The authors thank the ICE-L C-130 crew and investigators for their support. NSF and NCAR are acknowledged for financial support of the ICE-L field campaign, as well as the work of A.J. Heymsfield and D.C. Rogers. K.A. Pratt, C.J. Gaston, and K.A. Prather acknowledge NSF for support of ICE-L (ATM-0650659), laboratory studies (ATM-0650659 and ATM-0625526), A-ATOFMS development (ATM-0321362), and a graduate research fellowship for K.A. Pratt. C.H. Twohy and P.J. DeMott acknowledge NSF for ICE-L support (ATM-0612605 and ATM-0611936, respectively). S.M. Murphy and J.H. Seinfeld acknowledge NSF for support of ICE-L (ATM-0340832) and NASA for an Earth and Space Sciences Fellowship for S.M. Murphy. R.C. Moffet, T.R. Henn, and M.K. Gilles acknowledge support from the Department of Energy's Office of Biological and Environmental Research, Atmospheric Science Program, and Office of Basic Energy Sciences (DE-AC02-05CH11231), as well as the Lawrence Berkeley National Laboratory Glenn T. Seaborg Fellowship for R.C. Moffet. STEM-EDX was completed by Julia Sobolik (Oregon State University) and Traci Lersch (RJ LeeGroup, Inc). Cloud probe data were provided by NCAR/EOL under sponsorship of NSF (http://data.eol.ucar.edu). Total $\mathrm{PM}_{10}$ and $\mathrm{PM}_{2.5}$ mass concentrations in Utah were provided by the Utah State Division of Air Quality. Gregory Roberts (UCSD) is thanked for use of the CCNc. David Soller and Marith Reheis (USGS) are acknowledged for provision of the playa sediments map. ICE-L lidar and radar data were provided by Zhien Wang, Jeffrey French, and Samuel Haimov (University of Wyoming). Sonia Kreidenweis (Colorado State University) and Trude Eidhammer (NCAR) are thanked for discussions. The authors acknowledge NOAA ARL for the provision of the HYSPLIT READY website (http://www.arl.noaa.gov/ready.html) used in this publication. Salt Lake City radiosonde data were provided by the University of Wyoming; surface wind data were provided by MesoWest.

\section{References}

Abuduwaili, J., M. V. Gabchenko, and X. Junrong (2008), Eolian transport of salts-A case study in the area of Lake Ebinur (Xinjiang, northwest China), J. Arid Environ., 72(10), 1843-1852, doi:10.1016/j.jaridenv. 2008.05.006.

Aiken, A. C., et al. (2008), O/C and OM/OC ratios of primary, secondary, and ambient organic aerosols with high-resolution time-of-flight aerosol mass spectrometry, Environ. Sci. Technol., 42(12), 4478-4485, doi:10.1021/es703009q.

Allan, J. D., K. N. Bower, H. Coe, H. Boudries, J. T. Jayne, M. R. Canagaratna, D. B. Millet, A. H. Goldstein, P. K. Quinn, R. J. Weber, and D. R. Worsnop (2004), Submicron aerosol composition at Trinidad Head, California, during ITCT 2K2: Its relationship with gas phase volatile organic carbon and assessment of instrument performance, J. Geophys. Res., 109, D23S24, doi:10.1029/2003JD004208.

Andreae, M. O., and D. Rosenfeld (2008), Aerosol-cloud-precipitation interactions. Part 1 . The nature and sources of cloud-active aerosols, Earth Sci. Rev., 89(1-2), 13-41, doi:10.1016/j.earscirev.2008.03.001.

Bahreini, R., E. J. Dunlea, B. M. Matthew, C. Simons, K. S. Docherty, P. F. DeCarlo, J. L. Jimenez, C. A. Brock, and A. M. Middlebrook (2008), Design and operation of a pressure-controlled inlet for airborne sampling with an aerodynamic aerosol lens, Aerosol Sci. Technol., 42(6), 465-471, doi:10.1080/02786820802178514.

Bilde, M., and B. Svenningsson (2004), CCN activation of slightly soluble organics: The importance of small amounts of inorganic salt and particle phase, Tellus, Ser. B, 56(2), 128-134.

Blackwelder, E. (1931), The lowering of playas by deflation, Am. J. Sci., 2l(122), 140-144.

Blank, R. R., J. A. Young, and F. L. Allen (1999), Aeolian dust in a saline playa environment, Nevada, USA, J. Arid Environ., 41(4), 365-381, doi:10.1006/jare.1998.0491

Bryant, R. G., B. W. Sellwood, A. C. Millington, and N. A. Drake (1994), Marine-like potash evaporite formation on a continental playa-Casestudy from Chott-El-Djerid, southern Tunisia, Sediment. Geol., 90(3-4), 269-291, doi:10.1016/0037-0738(94)90043-4.

Cahill, T. A., T. E. Gill, J. S. Reid, E. A. Gearhart, and D. A. Gillette (1996), Saltating particles, playa crusts and dust aerosols at Owens (dry) Lake, California, Earth Surf. Processes Landforms, 21(7), 621-639, doi:10.1002/(SICI)1096-9837(199607)21:7<621::AID-ESP661>3.0. CO;2-E. 
Carrico, C. M., M. D. Petters, S. M. Kreidenweis, J. L. Collett, G. Engling, and W. C. Malm (2008), Aerosol hygroscopicity and cloud droplet activation of extracts of filters from biomass burning experiments, J. Geophys. Res., 113, D08206, doi:10.1029/2007JD009274.

Chen, J., R. J. Griffin, A. Grini, and P. Tulet (2007), Modeling secondary organic aerosol formation through cloud processing of organic compounds, Atmos. Chem. Phys., 7(20), 5343-5355, doi:10.5194/acp-75343-2007.

Cooper, W. A., and G. Vali (1981), The origin of ice in mountain cap clouds, J. Atmos. Sci., 38(6), 1244-1259, doi:10.1175/1520-0469 (1981) $038<1244$ :TOOIIM $>2.0$. CO;2.

Cziczo, D. J., D. M. Murphy, P. K. Hudson, and D. S. Thomson (2004) Single particle measurements of the chemical composition of cirrus ice residue during CRYSTAL-FACE, J. Geophys. Res., 109, D04201, doi:10.1029/2003JD004032.

DeCarlo, P. F., J. G. Slowik, D. R. Worsnop, P. Davidovits, and J. L. Jimenez (2004), Particle morphology and density characterization by combined mobility and aerodynamic diameter measurements. Part 1: Theory, Aerosol Sci. Technol., 38(12), 1185-1205, doi:10.1080/027868290903907.

DeMott, P. J., and D. C. Rogers (1990), Freezing nucleation rates of dilutesolution droplets measured between $-30^{\circ} \mathrm{C}$ and $-40^{\circ} \mathrm{C}$ in laboratory simulations of natural clouds, J. Atmos. Sci., 47(9), 1056-1064, doi:10.1175/1520-0469(1990)047<1056:FNRODS >2.0.CO;2.

Drewnick, F., et al. (2005), A new time-of-flight aerosol mass spectrometer (TOF-AMS) - Instrument description and first field deployment, Aerosol Sci. Technol., 39(7), 637-658, doi:10.1080/02786820500182040.

Drofa, A. S. (2006), Formation of cloud microstructure during hygroscopic seeding, Izv. Russ. Acad. Sci. Atmos. Oceanic Phys., Engl. Transl., 42(3), 326-336, doi:10.1134/S0001433806030066.

Droste, J. B. (1961), Clay minerals in sediments of Owens, China, Searles, Panamint, Bristol, Cadiz, and Danby Lake Basins, California, Geol. Soc. Am. Bull., 72(11), 1713-1722, doi:10.1130/0016-7606(1961)72[1713: CMISOO]2.0.CO;2.

Dusek, U., et al. (2006), Size matters more than chemistry for cloud-nucleating ability of aerosol particles, Science, 312(5778), 1375-1378, doi:10.1126/science.1125261.

Eidhammer, T., et al. (2010), Ice initiation by aerosol particles: Measured and predicted ice nuclei concentrations versus measured ice crystal concentrations in an orographic wave cloud, J. Atmos. Sci., in press.

Ervens, B., G. Feingold, G. J. Frost, and S. M. Kreidenweis (2004), A modeling study of aqueous production of dicarboxylic acids: 1. Chemical pathways and speciated organic mass production, J. Geophys. Res., 109, D15205, doi:10.1029/2003JD004387.

Field, P. R., O. Mohler, P. Connolly, M. Kramer, R. Cotton, A. J. Heymsfield, H. Saathoff, and M. Schnaiter (2006), Some ice nucleation characteristics of Asian and Saharan desert dust, Atmos. Chem. Phys., 6(10), 2991-3006, doi:10.5194/acp-6-2991-2006.

Formenti, P., W. Elbert, W. Maenhaut, J. Haywood, and M. O. Andreae (2003), Chemical composition of mineral dust aerosol during the Saharan Dust Experiment (SHADE) airborne campaign in the Cape Verde region, September 2000, J. Geophys. Res., 108(D18), 8576, doi:10.1029/ 2002JD002648.

Gard, E. E., et al. (1998), Direct observation of heterogeneous chemistry in the atmosphere, Science, 279(5354), 1184-1187, doi:10.1126/science. 279.5354.1184.

Ghate, V. P., B. A. Albrecht, P. Kollias, H. H. Jonsson, and D. W. Breed (2007), Cloud seeding as a technique for studying aerosol-cloud interactions in marine stratocumulus, Geophys. Res. Lett., 34, L14807, doi:10.1029/2007GL029748.

Gill, T. E. (1996), Eolian sediments generated by anthropogenic disturbance of playas: Human impacts on the geomorphic system and geomorphic impacts on the human system, Geomorphology, 17(1-3), 207-228, doi:10.1016/0169-555X(95)00104-D.

Gill, T. E., D. A. Gillette, T. Niemeyer, and R. T. Winn (2002), Elemental geochemistry of wind-erodible playa sediments, Owens Lake, California, Nucl. Instrum. Methods Phys. Res., Sect. B, 189(1-4), 209-213, doi:10.1016/S0168-583X(01)01044-8.

Güven, N., and P. F. Kerr (1966), Selected Great Basin playa clays, Am. Mineral., 51(7), 1056-1067.

Henke, B. L., E. M. Gullikson, and J. C. Davis (1993), X-ray interactions: Photoabsorption, scattering, transmission, and reflection at $E=50$ 30,000 eV, Z = 1-92, At. Data Nucl. Data Tables, 54(2), 181-342, doi:10.1006/adnd.1993.1013.

Hersey, S. P., A. Sorooshian, S. M. Murphy, R. C. Flagan, and J. H. Seinfeld (2009), Aerosol hygroscopicity in the marine atmosphere: A closure study using high-time-resolution, multiple-RH DASH-SP and size-resolved C-ToF-AMS data, Atmos. Chem. Phys., 9(7), 2543-2554, doi:10.5194/acp-9-2543-2009.
Heymsfield, A. J., and L. M. Miloshevich (1993), Homogeneous ice nucleation and supercooled liquid water in orographic wave clouds, J. Atmos. Sci., 50(15), 2335-2353, doi:10.1175/1520-0469(1993) 050<2335:HINASL $>2.0 . \mathrm{CO} ; 2$.

Heymsfield, A. J., L. M. Miloshevich, A. Slingo, K. Sassen, and D. O. C. Starr (1991), An observational and theoretical study of highly supercooled altocumulus, J. Atmos. Sci., 48(7), 923-945, doi:10.1175/15200469(1991)048<0923:AOATSO >2.0.CO;2.

Hildebrandt, L., N. M. Donahue, and S. N. Pandis (2009), High formation of secondary organic aerosol from the photo-oxidation of toluene, Atmos. Chem. Phys., 9(9), 2973-2986, doi:10.5194/acp-9-2973-2009.

Hobbs, P. V., D. A. Bowdle, and L. F. Radke (1985), Particles in the lower troposphere over the high plains of the United States. Part I: Size distributions, elemental compositions and morphologies, J. Appl. Meteorol., 24(12), 1344-1356, doi:10.1175/1520-0450(1985)024<1344:PITLTO> 2.0.CO;2.

Hopkins, R. J., A. V. Tivanski, B. D. Marten, and M. K. Gilles (2007), Chemical bonding and structure of black carbon reference materials and individual carbonaceous atmospheric aerosols, J. Aerosol Sci., 38(6), 573-591, doi:10.1016/j.jaerosci.2007.03.009.

Hudson, J. G. (2007), Variability of the relationship between particle size and cloud-nucleating ability, Geophys. Res. Lett., 34, L08801, doi:10.1029/2006GL028850.

Hudson, J. G., and C. F. Rogers (1986), Relationship between critical supersaturation and cloud droplet size: Implications for cloud mixing processes, J. Atmos. Sci., 43(21), 2341-2359, doi:10.1175/1520-0469 (1986)043<2341:RBCSAC $>2.0 . C O ; 2$.

Huffman, J. A., J. T. Jayne, F. Drewnick, A. C. Aiken, T. Onasch, D. R. Worsnop, and J. L. Jimenez (2005), Design, modeling, optimization, and experimental tests of a particle beam width probe for the Aerodyne aerosol mass spectrometer, Aerosol Sci. Technol., 39(12), 1143-1163, doi: $10.1080 / 02786820500423782$.

Intergovernmental Panel on Climate Change (2007), Climate Change 2007: The Physical Science Basis. Contribution of Working Group I to the Fourth Assessment Report of the Intergovernmental Panel on Climate Change, edited by S. Solomon et al., 996 pp., Cambridge Univ. Press, New York.

Jones, B. F., and D. M. Deocampo (2004), Geochemistry of saline lakes, in Treatise on Geochemistry, vol. 5, Surface and Ground Water, Weathering and Soils, edited by J. I. Drever, pp. 393-424, Elsevier, New York.

Junge, C., and E. McLaren (1971), Relationship of cloud nuclei spectra to aerosol size distribution and composition, J. Atmos. Sci., 28(3), 382-390, doi:10.1175/1520-0469(1971)028<0382:ROCNST $>2.0 . C O ; 2$.

Kelly, J. T., and A. S. Wexler (2006), Water uptake by aerosol: Water activity in supersaturated potassium solutions and deliquescence as a function of temperature, Atmos. Environ., 40(24), 4450-4468, doi:10.1016/j.atmosenv.2006.04.017.

Kelly, J. T., C. C. Chuang, and A. S. Wexler (2007), Influence of dust composition on cloud droplet formation, Atmos. Environ., 41(14), 2904-2916, doi:10.1016/j.atmosenv.2006.12.008.

Kilcoyne, A. L. D., et al. (2003), Interferometer-controlled scanning transmission X-ray microscopes at the Advanced Light Source, J. Synchrotron Radiat., 10(2), 125-136, doi:10.1107/S0909049502017739.

Koehler, K. A., S. M. Kreidenweis, P. J. DeMott, A. J. Prenni, and M. D. Petters (2007), Potential impact of Owens (dry) Lake dust on warm and cold cloud formation, J. Geophys. Res., 112, D12210, doi:10.1029/ 2007JD008413.

Koehler, K. A., S. M. Kreidenweis, P. J. DeMott, M. D. Petters, A. J. Prenni, and C. M. Carrico (2009), Hygroscopicity and cloud droplet activation of mineral dust aerosol, Geophys. Res. Lett., 36, L08805, doi:10.1029/ 2009GL037348.

Lasher-Trapp, S., S. Anderson-Bereznicki, A. Shackelford, C. H. Twohy, and J. G. Hudson (2008), An investigation of the influence of droplet number concentration and giant aerosol particles upon supercooled large drop formation in wintertime stratiform clouds, J. Appl. Meteorol. Climatol., 47(10), 2659-2678, doi:10.1175/2008JAMC1807.1.

Lowenstein, T. K., and L. A. Hardie (1985), Criteria for the recognition of salt-pan evaporites, Sedimentology, 32(5), 627-644, doi:10.1111/j.13653091.1985.tb00478.x.

Matthew, B. M., A. M. Middlebrook, and T. B. Onasch (2008), Collection efficiencies in an Aerodyne aerosol mass spectrometer as a function of particle phase for laboratory generated aerosols, Aerosol Sci. Technol. 42(11), 884-898, doi:10.1080/02786820802356797.

Moffet, R. C., et al. (2008a), Characterization of aerosols containing Zn, $\mathrm{Pb}$, and $\mathrm{Cl}$ from an industrial region of Mexico City, Environ. Sci. Technol., 42(19), 7091-7097, doi:10.1021/es7030483.

Moffet, R. C., X. Qin, T. Rebotier, H. Furutani, and K. A. Prather (2008b), Chemically segregated optical and microphysical properties of ambient 
aerosols measured in a single-particle mass spectrometer, J. Geophys. Res., 113, D12213, doi:10.1029/2007JD009393.

Munger, J. W., J. Collett, B. Daube, and M. R. Hoffmann (1989), Chemical composition of coastal stratus clouds: Dependence on droplet size and distance from the coast, Atmos. Environ., 23(10), 2305-2320, doi:10.1016/0004-6981(89)90192-3.

Murphy, D. M., D. J. Cziczo, P. K. Hudson, D. S. Thomson, J. C. Wilson, T. Kojima, and P. R. Buseck (2004), Particle generation and resuspension in aircraft inlets when flying in clouds, Aerosol Sci. Technol., 38(4), 400-408, doi:10.1080/02786820490443094.

Niedermeier, D., H. Wex, J. Voigtländer, F. Stratmann, E. Brüggemann, A. Kiselev, H. Henk, and J. Heintzenberg (2008), LACIS-measurements and parameterization of sea-salt particle hygroscopic growth and activation, Atmos. Chem. Phys., 8(3), 579-590, doi:10.5194/acp8-579-2008.

Noone, K. J., J. A. Ogren, J. Heintzenberg, R. J. Charlson, and D. S. Covert (1988), Design and calibration of a counterflow virtual impactor for sampling of atmospheric fog and cloud droplets, Aerosol Sci. Technol., 8(3), 235-244, doi:10.1080/02786828808959186.

Ogren, J. A., and R. J. Charlson (1992), Implications for models and measurements of chemical inhomogeneities among cloud droplets, Tellus, Ser. B, 44(3), 208-225, doi:10.1034/j.1600-0889.1992.t01-2-00004.x.

Patterson, E. M., and D. A. Gillette (1977), Commonalities in measured size distributions for aerosols having a soil-derived component, J. Geophys. Res., 82(15), 2074-2082, doi:10.1029/JC082i015p02074.

Pelletier, J. D. (2006), Sensitivity of playa windblown-dust emissions to climatic and anthropogenic change, J. Arid Environ., 66(1), 62-75, doi:10.1016/j.jaridenv.2005.10.010.

Petters, M. D., and S. M. Kreidenweis (2007), A single parameter representation of hygroscopic growth and cloud condensation nucleus activity, Atmos. Chem. Phys., 7(8), 1961-1971, doi:10.5194/acp-7-1961-2007.

Pratt, K. A., et al. (2009), Development and characterization of an aircraft aerosol time-of-flight mass spectrometer, Anal. Chem., 81(5), 1792-1800, doi:10.1021/ac801942r.

Prenni, A. J., P. J. DeMott, C. Twohy, M. R. Poellot, S. M. Kreidenweis, D. C. Rogers, S. D. Brooks, M. S. Richardson, and A. J. Heymsfield (2007), Examinations of ice formation processes in Florida cumuli using ice nuclei measurements of anvil ice crystal particle residues, J. Geophys. Res., 112, D10221, doi:10.1029/2006JD007549.

Prenni, A. J., M. D. Petters, S. M. Kreidenweis, C. L. Heald, S. T. Martin, P. Artaxo, R. M. Garland, A. G. Wollny, and U. Pöschl (2009), Relative roles of biogenic emissions and Saharan dust as ice nuclei in the Amazon basin, Nat. Geosci., 2(6), 402-405, doi:10.1038/ngeo517.

Prospero, J. M., P. Ginoux, O. Torres, S. E. Nicholson, and T. E. Gill (2002), Environmental characterization of global sources of atmospheric soil dust identified with the Nimbus 7 Total Ozone Mapping Spectrometer (TOMS) absorbing aerosol product, Rev. Geophys., 40(1), 1002, doi:10.1029/2000RG000095.

Rader, D. J., and V. A. Marple (1985), Effect of ultra-Stokesian drag and particle interception on impaction characteristics, Aerosol Sci. Technol., 4(2), 141-156, doi:10.1080/02786828508959044.

Reheis, M. C. (1997), Dust deposition downwind of Owens (dry) Lake, 1991-1994: Preliminary findings, J. Geophys. Res., 102(D22), 25,999-26,008, doi:10.1029/97JD01967.

Reheis, M. C. (2006), A 16-year record of eolian dust in Southern Nevada and California, USA: Controls on dust generation and accumulation, J. Arid Environ., 67(3), 487-520, doi:10.1016/j.jaridenv.2006.03.006.

Reheis, M. C., and R. Kihl (1995), Dust deposition in southern Nevada and California, 1984-1989: Relations to climate, source area, and source lithology, J. Geophys. Res., 100(D5), 8893-8918, doi:10.1029/ 94JD03245.

Reid, J. S., R. G. Flocchini, T. A. Cahill, and R. S. Ruth (1994), Local meteorological, transport, and source aerosol characteristics of late autumn Owens Lake (dry) dust storms, Atmos. Environ., 28(9), 1699-1706, doi:10.1016/1352-2310(94)90315-8.

Reynolds, R. L., J. C. Yount, M. Reheis, H. Goldstein, P. Chavez, R. Fulton, J. Whitney, C. Fuller, and R. M. Forester (2007), Dust emission from wet and dry playas in the Mojave desert, USA, Earth Surf. Processes Landforms, 32(12), 1811-1827, doi:10.1002/esp.1515.

Roberts, G. C., and A. Nenes (2005), A continuous-flow streamwise thermal-gradient CCN chamber for atmospheric measurements, Aerosol Sci. Technol., 39(3), 206-221, doi:10.1080/027868290913988.

Roberts, G. C., P. Artaxo, J. Zhou, E. Swietlicki, and M. O. Andreae (2002), Sensitivity of CCN spectra on chemical and physical properties of aerosol: A case study from the Amazon Basin, J. Geophys. Res., 107(D20), 8070, doi:10.1029/2001JD000583.

Rogers, D. C., P. J. DeMott, S. M. Kreidenweis, and Y. Chen (2001), A continuous-flow diffusion chamber for airborne measurements of ice nuclei, J. Atmos. Oceanic Technol., 18, 725-741, doi:10.1175/1520 0426(2001)018<0725:ACFDCF $>2.0 . \mathrm{CO} ; 2$.

Rose, D., S. S. Gunthe, E. Mikhailov, G. P. Frank, U. Dusek, M. O. Andreae, and U. Pöschl (2008), Calibration and measurement uncertainties of a continuous-flow cloud condensation nuclei counter (DMTCCNC): CCN activation of ammonium sulfate and sodium chloride aerosol particles in theory and experiment, Atmos. Chem. Phys., 8(5), 1153-1179, doi:10.5194/acp-8-1153-2008

Rudich, Y., O. Khersonsky, and D. Rosenfeld (2002), Treating clouds with a grain of salt, Geophys. Res. Lett., 29(22), 2060, doi:10.1029/ 2002GL016055

Russell, I. C. (1883), Playas and playa-lakes, Pop. Sci., 22, 380-383.

Silva, P. J., D. Y. Liu, C. A. Noble, and K. A. Prather (1999), Size and chemical characterization of individual particles resulting from biomass burning of local Southern California species, Environ. Sci. Technol., 33(18), 3068-3076, doi:10.1021/es980544p.

Singer, A., T. Zobeck, L. Poberezsky, and E. Argaman (2003), The $\mathrm{PM}_{10}$ and $\mathrm{PM}_{2.5}$ dust generation potential of soils/sediments in the Southern Aral Sea Basin, Uzbekistan, J. Arid Environ., 54(4), 705-728, doi:10.1006/ jare.2002.1084

Soller, D. R., and M. C. Reheis (2004), Surficial materials in the conterminous United States, U.S. Geol. Surv. Open File Rep., 03-275, scale $1: 5,000,000$.

Sullivan, R. C., and K. A. Prather (2007), Investigations of the diurnal cycle and mixing state of oxalic acid in individual particles in Asian aerosol outflow, Environ. Sci. Technol., 41(23), 8062-8069, doi:10.1021 es071134g.

Sullivan, R. C., M. J. K. Moore, M. D. Petters, S. M. Kreidenweis, G. C. Roberts, and K. A. Prather (2009), Effect of chemical mixing state on the hygroscopicity and cloud nucleation properties of calcium mineral dust particles, Atmos. Chem. Phys., 9(10), 3303-3316, doi:10.5194/acp-93303-2009.

Sun, Y., et al. (2009), Size-resolved aerosol chemistry on Whistler Mountain, Canada with a high-resolution aerosol mass spectrometer during INTEX-B, Atmos. Chem. Phys., 9(9), 3095-3111, doi:10.5194/acp-93095-2009.

Tang, I. N., A. C. Tridico, and K. H. Fung (1997), Thermodynamic and optical properties of sea salt aerosols, J. Geophys. Res., 102(D19), 23,269-23,275, doi:10.1029/97JD01806.

Toner, S. M., L. G. Shields, D. A. Sodeman, and K. A. Prather (2008), Using mass spectral source signatures to apportion exhaust particles from gasoline and diesel powered vehicles in a freeway study using UF-ATOFMS, Atmos. Environ., 42(3), 568-581, doi:10.1016/j.atmosenv. 2007.08.005.

Twohy, C. H., and J. R. Anderson (2008), Droplet nuclei in non-precipitating clouds: Composition and size matter, Environ. Res. Lett., 3(4), 045002 , doi:10.1088/1748-9326/3/4/045002.

Twohy, C. H., and M. R. Poellot (2005), Chemical characteristics of ice residual nuclei in anvil cirrus clouds: Evidence for homogeneous and heterogeneous ice formation, Atmos. Chem. Phys., 5(8), 2289-2297, doi:10.5194/acp-5-2289-2005.

Twohy, C. H., P. H. Austin, and R. J. Charlson (1989), Chemical consequences of the initial diffusional growth of cloud droplets: A clean marine case, Tellus, Ser. B, 41(1), 51-60, doi:10.1111/j.1600-0889. 1989.tb00124.x.

Twohy, C. H., A. J. Schanot, and W. A. Cooper (1997), Measurement of condensed water content in liquid and ice clouds using an airborne counterflow virtual impactor, J. Atmos. Oceanic Technol., 14, 197-202, doi:10.1175/1520-0426(1997)014<0197:MOCWCI>2.0.CO;2.

Twohy, C. H., J. W. Strapp, and M. Wendisch (2003), Performance of a counterflow virtual impactor in the NASA Icing Research Tunnel, J. Atmos. Oceanic Technol., 20, 781-790.

Twohy, C. H., et al. (2009), Saharan dust particles nucleate droplets in eastern Atlantic clouds, Geophys. Res. Lett., 36, L01807, doi:10.1029/ 2008GL035846

Washington, R., M. Todd, N. J. Middleton, and A. S. Goudie (2003), Duststorm source areas determined by the total ozone monitoring spectrometer and surface observations, Ann. Assoc. Am. Geogr., 93(2), 297-313, doi:10.1111/1467-8306.9302003.

P. J. DeMott, Department of Atmospheric Science, Colorado State University, Fort Collins, CO 80523, USA

P. R. Field, Atmospheric Processes and Parameterizations, Met Office, Exeter EX1 3PB, UK

C. J. Gaston, Scripps Institution of Oceanography, University of California, San Diego, La Jolla, CA 92093, USA.

M. K. Gilles and R. C. Moffet, Chemical Sciences Division, Lawrence Berkeley National Laboratory, Berkeley, CA 94720, USA. 
T. R. Henn, Department of Physics, University of Würzburg, Am Hubland, D-97074 Würzburg, Germany.

A. J. Heymsfield, Mesoscale and Microscale Meteorology Division, National Center for Atmospheric Research, Boulder, CO 80305, USA.

S. M. Murphy, Chemical Sciences Division, Earth System Research Laboratory, National Oceanic and Atmospheric Administration, Boulder, CO 80305, USA.

K. A. Prather, Department of Chemistry and Biochemistry, University of California, San Diego, La Jolla, CA 92093, USA. (kprather@ucsd.edu)
K. A. Pratt, Department of Chemistry, Purdue University, West Lafayette, IN 47907, USA.

D. C. Rogers, Earth Observing Laboratory, National Center for Atmospheric Research, Boulder, CO 80305, USA.

J. H. Seinfeld, Division of Chemistry and Chemical Engineering, California Institute of Technology, Pasadena, CA 91125, USA.

C. H. Twohy, Department of Oceanic and Atmospheric Sciences, Oregon State University, Corvallis, OR 97331, USA 